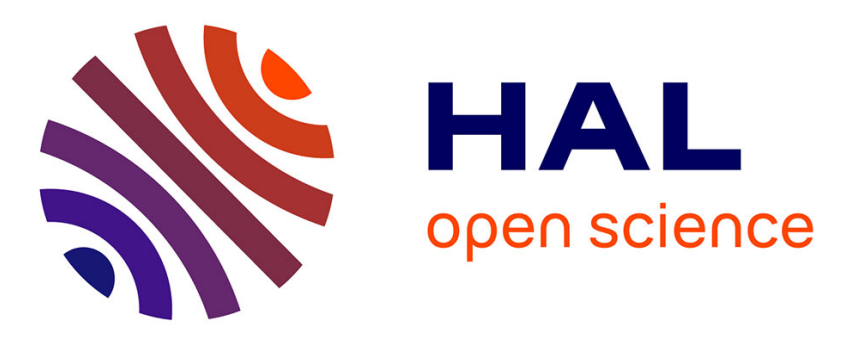

\title{
Gold-Catalyzed Rearrangement of (Silylcyclopropenyl)methyl Ethers into (Silylmethylene)cyclopropanes
}

Florence Hiault, Alexis Archambeau, Frédéric Miege, Christophe Meyer, Janine Cossy

\section{To cite this version:}

Florence Hiault, Alexis Archambeau, Frédéric Miege, Christophe Meyer, Janine Cossy. GoldCatalyzed Rearrangement of (Silylcyclopropenyl)methyl Ethers into (Silylmethylene)cyclopropanes. Synthesis: Journal of Synthetic Organic Chemistry, 2016, 48 (19), pp.3165-3174. 10.1055/s-00351561486 . hal-03229300

\section{HAL Id: hal-03229300 https://hal.science/hal-03229300}

Submitted on 8 Jul 2021

HAL is a multi-disciplinary open access archive for the deposit and dissemination of scientific research documents, whether they are published or not. The documents may come from teaching and research institutions in France or abroad, or from public or private research centers.
L'archive ouverte pluridisciplinaire HAL, est destinée au dépôt et à la diffusion de documents scientifiques de niveau recherche, publiés ou non, émanant des établissements d'enseignement et de recherche français ou étrangers, des laboratoires publics ou privés. 


\title{
Gold-Catalyzed Rearrangement of (Silylcyclopropenyl)methyl Ethers into (Silylmethylene)cyclopropanes
}

\author{
Florence Hiault, Alexis Archambeau, Frédéric Miege, Christophe Meyer* and Janine Cossy* \\ Laboratory of Organic Chemistry, Institute of Chemistry, Biology and Innovation (CBI) \\ ESPCI Paris, CNRS (UMR8231), PSL Research University, 10 rue Vauquelin, 75231 Paris Cedex 05, France \\ Fax: +33140704660 \\ E-mail: christophe.meyer@espci.fr, janine.cossy@espci.fr \\ Received: The date will be inserted once the manuscript is accepted. \\ Warmly dedicated to Professor Jean-François Normant on the occasion of his $80^{\text {th }}$ birthday
}

\begin{abstract}
Methoxymethyl ethers derived from (2-dimethylphenylsilylcyclopropenyl carbinols undergo a gold-catalyzed rearrangement leading to ((Z)-dimethylphenylsilylmethylene)cyclopropanes in moderate to high yields and methyl formate as a by-product. This transformation proceeds by initial regioselective ring-opening of the three-membered ring leading to an $\alpha$-silyl vinyl gold carbenoid. This latter organogold species evolves by a 1,5-hydride transfer which triggers subsequent rearrangement involving loss of methyl formate, $2 \pi$-electrocyclization of the resulting allylic cation and elimination of the metal to regenerate the catalyst.
\end{abstract}

Key words: Cyclopropenes, Gold catalysis, Strained cycles, Rearrangement, Hydride transfer

Transition metal-catalyzed reactions of cyclopropenes have attracted considerable mechanistic and synthetic interest. $^{1,2}$ Indeed, transition metals are able to catalyze the addition of several reagents across the carbon-carbon double bond of cyclopropenes but also a variety of transformations accompanied by ringcleavage. ${ }^{1,2}$ It is well-known that many electrophilic metal complexes can trigger the ring-opening of cyclopropenes to generate vinyl metal carbenoids which can undergo nucleophilic additions, rearrangements or be involved in cyclopropanation or $\mathrm{C}-\mathrm{H}$ insertion reactions. ${ }^{1,2}$ In 2008, the groups of Shi ${ }^{3}$ and $\mathrm{Lee}^{4}$ disclosed the first examples of gold(I)catalyzed reactions of cyclopropenes. Their pioneering work and subsequent contributions demonstrated that the gold carbenoids resulting from the ring-opening of cyclopropenes can participate in inter- or intramolecular addition of nucleophiles ${ }^{3-6}$ and olefin cyclopropanation. ${ }^{6}$ Cyclopropenyl carbinol derivatives, readily available by addition of cyclopropenyl organolithium reagents to aldehydes, ${ }^{7}$ have been successfully involved in gold-catalyzed reactions. To date, Hyland, Ariafard et al. reported the gold-catalyzed isomerization of cyclopropenylmethyl acetates $\mathbf{A}$ into 2-acetoxy dienes that proceeds by regioselective ring-opening to generate the gold carbenoids $\mathbf{B}$ at $\mathrm{C} 1$ followed by 1,2-acetoxy shift and elimination of the metal. ${ }^{5 \mathrm{c}}$ Our group has shown that allyl ethers D derived from 3,3-dimethylcyclopropenyl carbinols underwent regioselective ringopening to generate gold carbenoids $\mathbf{E}$ at $\mathrm{C} 2$ which effected the highly diastereoselective intramolecular cyclopropanation of the remote olefin to afford 3-oxabicyclo[4.1.0] heptanes $\mathbf{F}$.c,d $^{6 c}$ The substituents of the cyclopropene double bond in cyclopropenyl carbinol derivatives $\mathbf{A}$ and $\mathbf{D}$ were crucial to achieve regioselective ring-opening. DFT calculations by Hyland, Ariafard et al. indicated that the regioselectivity of the ring-opening of a cyclopropene in the presence of a gold(I) complex is governed by the relative $\pi$-donating abilities of substituents at $\mathrm{C} 1$ and $\mathrm{C} 2{ }^{8,9}$ This study accounts well for the observed regioselectivities of the ring-opening of cyclopropenes $\mathbf{A}$ and $\mathbf{D}$ because the $\pi$-donating abilities of the substituents vary in the following order $\mathrm{Me}>\mathrm{CH}(\mathrm{OR})>\mathrm{H}^{8}$

Herein, we report a new gold-catalyzed rearrangement of ethers derived from (silylcyclopropenyl) carbinols G which led to (silylmethylene)cyclopropanes I and proceeds by rearrangement of $\alpha$-silyl vinyl gold carbenoids $\mathbf{H}$ triggered by a 1,5-hydride transfer (Scheme 1).

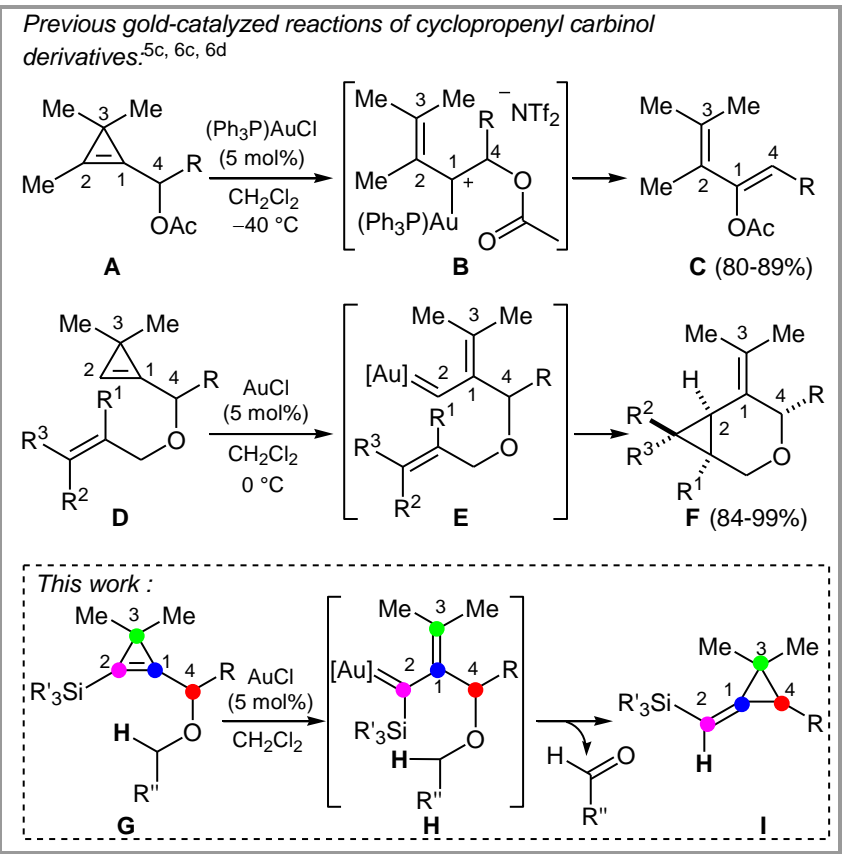

Scheme 1 Gold-catalyzed reactions of cyclopropenyl carbinol derivatives.

With the goal of extending the scope of the goldcatalyzed cycloisomerization of 1,6-cyclopropeneenes $\mathbf{D}$, the reactivity of related substrates possessing a substituent at $\mathrm{C} 2$ was investigated. However, $\pi$-donating groups able to stabilize an adjacent 
positive charge would alter the regioselectivity of the ring-opening and favor the formation of a regioisomeric gold carbenoid at $\mathrm{C} 1{ }^{6 c}$ We reasoned that a silyl group should not alter the regioselectivity of the ring-opening because of the $\beta$ effect of silicon, ${ }^{10}$ although DFT calculations indicated that the ring-opening of trimethylsilylcyclopropene would produce an $\alpha$-silyl vinyl gold carbenoid with a very modest preference. ${ }^{8}$ A 1,2-silyl migration could also occur, as observed in the platinum-catalyzed isomerization of silylcyclopropenes into silylallenes. ${ }^{11}$

Trimethylsilylcyclopropene 1a was prepared and treated with a catalytic amount of $\mathrm{AuCl}(5 \mathrm{~mol} \%)$ in $\mathrm{CH}_{2} \mathrm{Cl}_{2}$ (rt, 2 h). A clean reaction occurred and analysis of the crude material by ${ }^{1} \mathrm{H}$ NMR spectroscopy indicated the formation of a new compound which was identified as ((Z)-trimethylsilylmethylene)cyclopropane $\mathbf{2}$. This compound was formed with high stereoselectivity $(Z / E \geq 95: 5)^{12}$ and isolated in $85 \%$ yield. Interestingly, the presence of the silyl group altered the reactivity and suppressed the intramolecular olefin cyclopropanation process. At this stage, the fate of the allyloxy group of 1a which is not present in the rearranged product $\mathbf{2}$ remained uncertain. This issue was solved by examination of the reactivity of the structurally related trimethylsilylcyclopropene $\mathbf{1 b}$ possessing a benzyl ether. The goldcatalyzed rearrangement of $\mathbf{1 b}$ proceeded under equally mild conditions and also produced (silylmethylene)cyclopropane $\mathbf{2}(87 \%)$ but in this case, benzaldehyde $\mathbf{3 b}$ was identified as the byproduct. This finding suggested that acrolein 3a had presumably been generated as a volatile by-product during the gold-catalyzed rearrangement of $1 \mathbf{a}$ but was lost during work-up (Scheme 2).

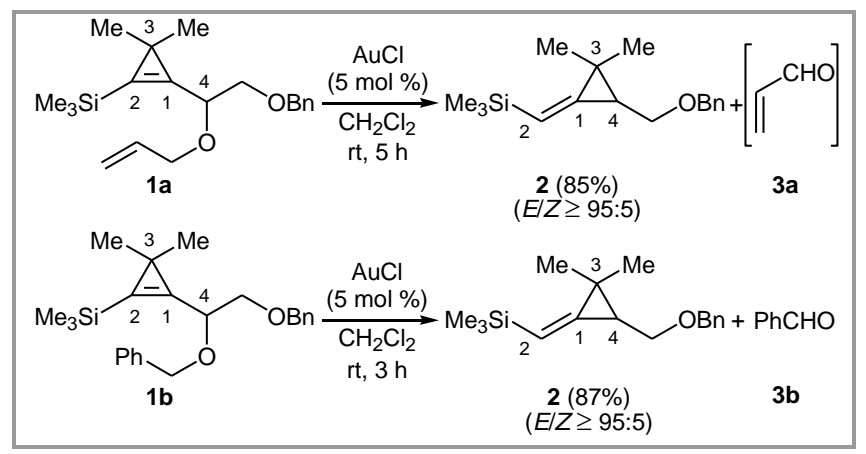

Scheme 2 Gold-catalyzed rearrangement of allyl and benzyl silylcyclopropenylmethyl ethers $\mathbf{1 a}$ and $\mathbf{1 b}$.

To explain the formation of alkylidenecyclopropane 2 from (trimethylsilylcyclopropenyl)methyl ethers 1a and $\mathbf{1 b}$, a plausible mechanism would involve initial regioselective ring-opening of the three-membered ring to generate the corresponding $\alpha$-trimethylsilyl vinyl gold carbenoids $4 \mathbf{a}$ and $4 \mathbf{b}$ at $\mathrm{C} 2$. Coordination of the gold moiety to the $\mathrm{C} 1=\mathrm{C} 2$ double bond with unsymmetrical binding through $\mathrm{C} 2$ would induce a a partial charge depletion at $\mathrm{C} 1,{ }^{9}$ stabilized by the silicon $\beta$ effect. ${ }^{10}$ The electrophilic organogold carbenoids $\mathbf{4 a}$ and $\mathbf{4 b}$ would then undergo a 1,5 -hydride transfer, assisted by the oxygen atom, ${ }^{13}$ producing the corresponding $\alpha$-silyl allyl gold complexes 5a and 5b with an oxonium ion leaving group at $\mathrm{C} 4$. The rearrangement of these latter species into (silylmethylene)cyclopropane $\mathbf{2}$ would then involve three elementary key steps: i) ionization of the C4-O bond with elimination of acrolein or benzaldehyde, ${ }^{14}$ ii) a $2 \pi$-electrocyclization leading to the formation of the $\mathrm{C} 3-\mathrm{C} 4$ bond and hence constructing a three-membered ring and iii) the elimination of the gold moiety resulting in the formation of the $\mathrm{C} 2=\mathrm{C} 1$ alkenylsilane moiety in compound 2 (Scheme 3 ).

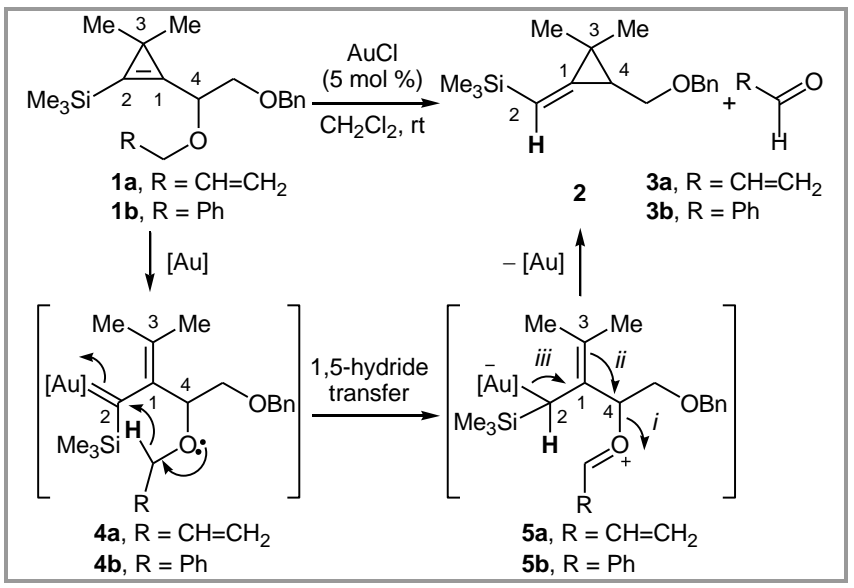

Scheme 3 Plausible mechanism accounting for the formation of (silylmethylene)cyclopropane $\mathbf{2}$ from $\mathbf{1 a}$ and $\mathbf{1 b}$.

The occurrence of a 1,5-hydride transfer was confirmed by the rearrangement of the gem-deuterated benzyl ether 1'b which selectively produced (silyldeuteromethylene)cyclopropane 2' (89\%) and deuterated benzaldehyde 3'b (Scheme 4).

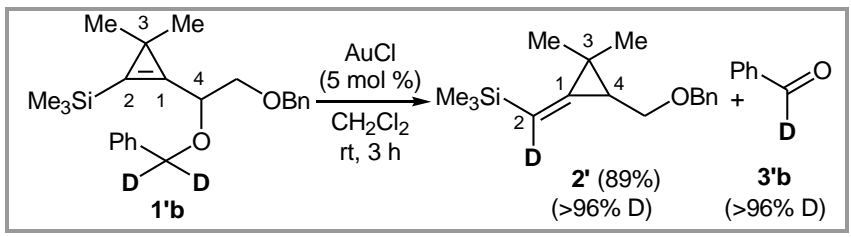

Scheme 4 Gold-catalyzed rearrangement of gem-dideuterated benzyl ether 1'b.

It is worth pointing out that the rearrangement of the cyclopropenylmethyl ether $\mathbf{1 b}$ into (silylmethylene)cyclopropane 2 shares some similarities with the goldcatalyzed rearrangement of propargyl benzyl ethers into allenes, which proceeds by a 1,5-hydride shift onto alkynes activated by the gold(I) complex and subsequent fragmentation with loss of benzaldehyde. ${ }^{15}$

Before studying the scope of this new gold catalyzed rearrangement, our attention was drawn to the search of alternative (silylcyclopropenyl)methyl ether 
substrates. Indeed, a dimethylphenylsilyl substituent rather than a trimethylsilyl group would potentially offer more opportunities for further functionalization of the carbon-silicon bond. ${ }^{16}$ Additionally, the corresponding silylated cyclopropenyl carbinol precusors $\mathbf{J}$ would be easily obtained by addition of the organolithium generated from the non volatile and readily available 3,3-dimethylphenylsilylcyclopropene $\mathbf{6}^{17}$ to various aldehydes. However, allylation or benzylation of silylcyclopropenyl carbinols $\mathbf{J}$ cannot be conveniently achieved under usual basic conditions ( $\mathrm{NaH}$ or $t$-BuOK, AllyBr or $\mathrm{BnBr}$, THF) because competitive cleavage of the $\mathrm{C}-\mathrm{Si}$ bond occurred. Benzyl ethers were also not appealing substrates because the non-volatile by-product benzaldehyde has to be separated by chromatography from the rearranged products. For these reasons, (dimethylphenylsilylcyclopropenyl)methyl methoxymethyl (MOM) ethers $\mathbf{K}$ were eventually selected as substrates. Indeed, their synthesis from cyclopropenyl carbinols $\mathbf{J}$ would not require strongly basic conditions and their gold-catalyzed rearrangement into (silylmethylene)cyclopropanes $\mathbf{L}$ would produce methyl formate as a volatile by-product (Scheme 5).

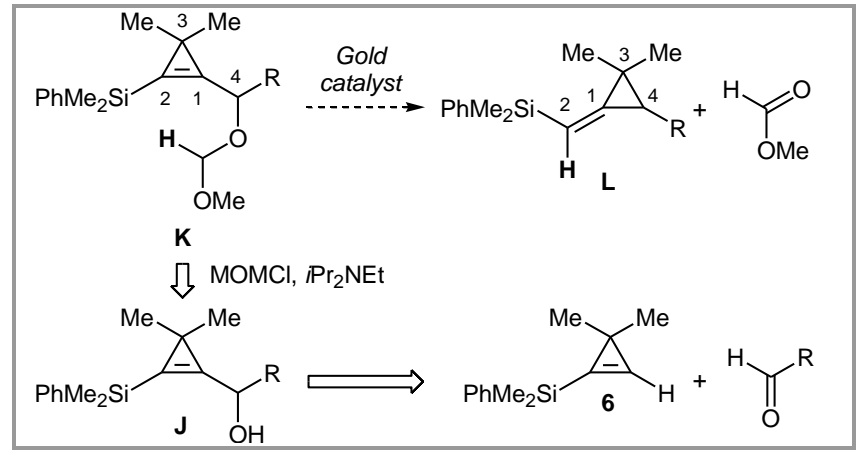

Scheme 5 Selection of (dimethylphenylsilyl)cyclopropenylmethyl MOM ethers $\mathbf{K}$ as substrates for the gold-catalyzed rearrangement.

Several (dimethylphenylsilylcyclopropenyl)methyl ethers were prepared by addition of the organolithium reagent 7, generated from silylcyclopropene 6 ( $n$-BuLi, THF, $-78{ }^{\circ} \mathrm{C}$ to $-10{ }^{\circ} \mathrm{C}$ ), to various aldehydes $\left(-50{ }^{\circ} \mathrm{C}\right.$ to $\left.-10{ }^{\circ} \mathrm{C}\right)$ followed by conversion of the resulting secondary alcohols $\mathbf{8 a - 8 j} / \mathbf{8 j}$ ' into the corresponding $\mathrm{MOM}$ ethers under standard conditions (MOMCl, $i \mathrm{Pr}_{2} \mathrm{NEt}, \mathrm{CH}_{2} \mathrm{Cl}_{2}, 0{ }^{\circ} \mathrm{C}$ to rt). The resulting ethers $\mathbf{9 a}-\mathbf{9 j} / \mathbf{9 j}$ ' were isolated in $15 \%$ to $90 \%$ overall yields (two steps from the corresponding aldehydes) without any optimization. When 2-phenylpropionaldehyde was used as the substrate, an inseparable 90:10 mixture of syn/anti diastereomers $\mathbf{9 j} / \mathbf{9 j}$ ' was obtained (75\% overall yield), as a result of a Felkin-Anh addition mode of the cyclopropenyl organolithium reagent 7 (Scheme 6). ${ }^{17,18}$

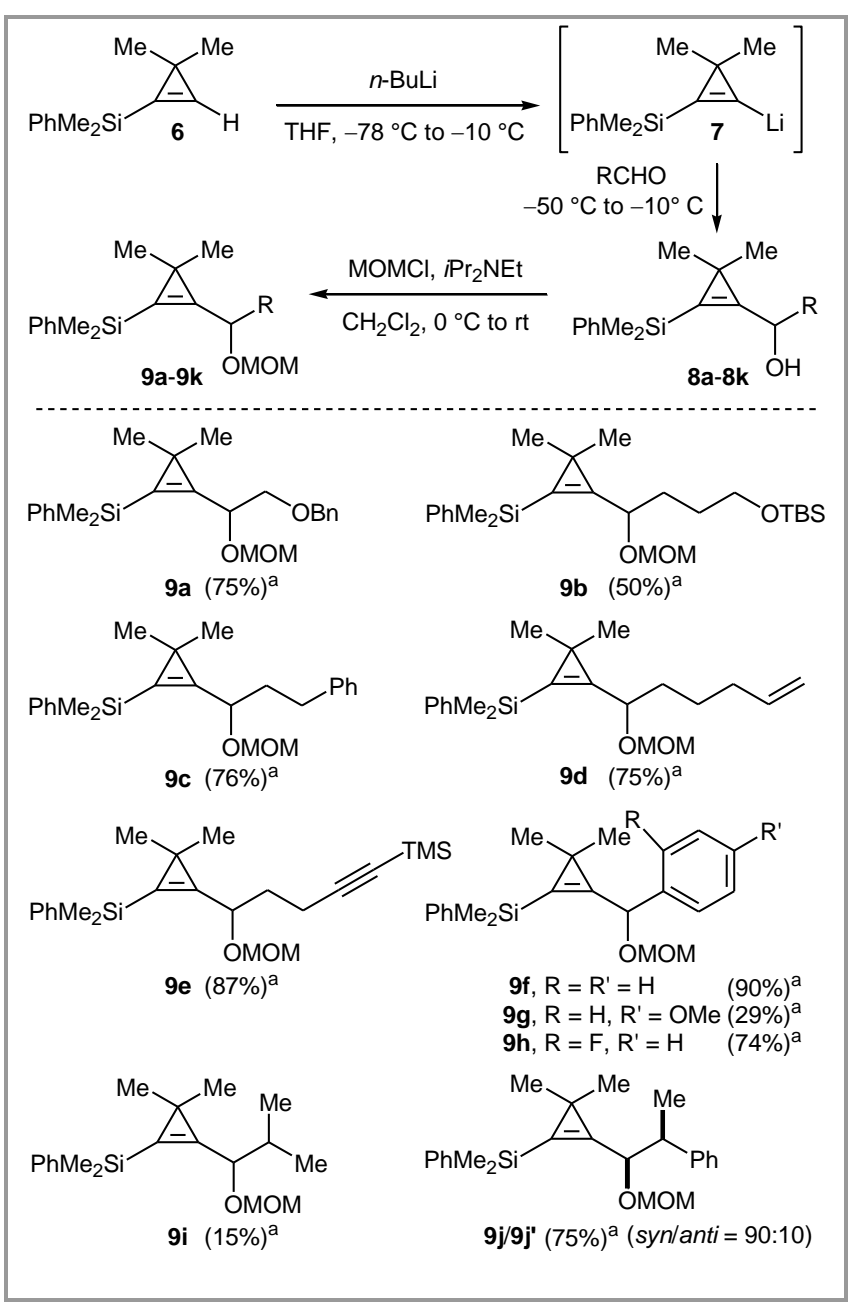

Scheme 6 Preparation of the (dimethylphenylsilyl)cyclopropenylmethyl MOM ether substrates $\mathbf{9 a - 9 j / 9 j}$ '. ${ }^{a}$ Overall yield from the corresponding aldehydes (two steps).

The initial screening of the reaction conditions was carried out with substrate 9a. As observed previously with the allyl and benzyl ethers 1a and $\mathbf{1 b}$ (Scheme 2), the rearrangement of MOM ether 9a was efficiently catalyzed by $\mathrm{AuCl}(5 \mathrm{~mol} \%)\left(\mathrm{CH}_{2} \mathrm{Cl}_{2}, \mathrm{rt}, 8 \mathrm{~h}\right)$, albeit a slightly longer reaction time was required. The ((Z)-dimethylphenylsilylmethylene)cyclopropane $\mathbf{1 0 a}$ was formed as a single geometric isomer and was isolated in $86 \%$ yield. ${ }^{12}$ Because $\mathrm{AuCl}$ does not lead to a well-defined catalyst in $\mathrm{CH}_{2} \mathrm{Cl}_{2},{ }^{19}$ the use of the gold(I) complexes $\left(\mathrm{Ph}_{3} \mathrm{P}\right) \mathrm{AuNTf}_{2}{ }^{20}$ and $[\mathrm{Au}]-\mathrm{I}^{21}$ was also attempted. Although substrate 9a was rapidly consumed with these catalysts, the formation of 10a was immediately accompanied by numerous sideproducts that could not be readily separated nor identified. ${ }^{22}$ By contrast, the rearrangement of $9 \mathbf{a}$ could be catalyzed by the gold(III) complex [Au]-II ${ }^{23}$ and provided 10a in good yield (74\%) (Scheme 7).

The best result was obtained with $\mathrm{AuCl}$ which was hence used as a catalyst for the investigation of the rearrangement of the other substrates $\mathbf{9 b} \mathbf{9} \mathbf{9} \mathbf{j} \mathbf{9 j}$ ' (Table 1). 


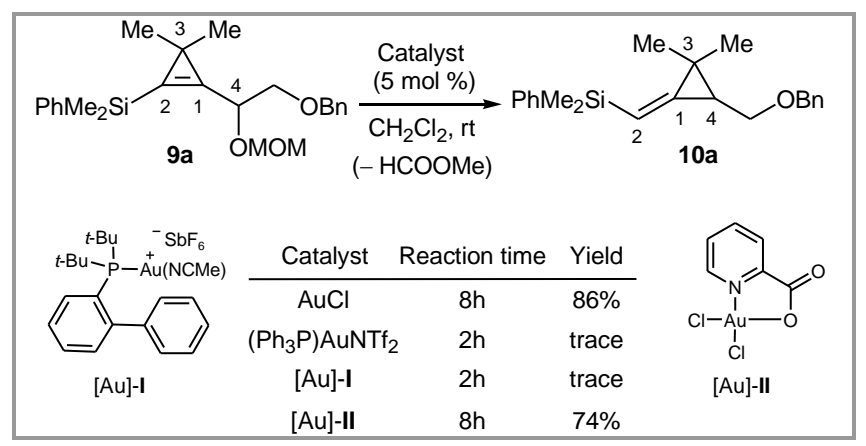

Scheme 7 Gold-catalyzed rearrangement of MOM ether 9a.

The gold-catalyzed rearrangement of ether $\mathbf{9 b}$ possessing a (3-silyloxypropyl) substituent proceeded well and provided compound $\mathbf{1 0 b}$ in $74 \%$ yield (Table 1, entry 1). The reaction is compatible with a phenyl group or a terminal alkene on the chain as shown with compounds $\mathbf{9 c}$ and $\mathbf{9 d}$, respectively, which afforded the corresponding alkylidenecyclopropanes 10c (78\%) and 10d (74\%) (Table 1, entries 2 and 3). Interestingly, a (trimethylsilyl)alkyne did not interfere, as illustrated in the case of substrate $9 \mathbf{e}$ which underwent an efficient chemoselective rearrangement leading to methylenecyclopropane 10e in $86 \%$ yield (Table 1, entry 4). ${ }^{24}$ The reactivity of aryl methyl ethers $9 \mathbf{f}-9 \mathbf{h}$ was next examined. The rearrangement of the phenyl substituted substrate 9 f led to compound $10 f$ albeit in moderate yield (49\%) (Table 1, entry 5), because of competitive formation of unidentified byproducts. Substrate $\mathbf{9 g}$ possessing an electron-rich aromatic ring decomposed under the reaction conditions (Table 1, entry 6). The rearrangement of $\mathbf{9 h}$ possessing a 2-fluorophenyl group produced alkylidenecyclopropane $\mathbf{1 0 h}$ in low yield (36\%) (Table 1, entry 7). Thus, ethers derived from aryl cyclopropenyl carbinols were not viable substrates in this gold-catalyzed rearrangement. Branched alkyl groups were tolerated as illustrated by the goldcatalyzed rearrangement of cyclopropenyl-silane $\mathbf{9 i}$ substituted by an isopropyl which produced alkylidenecyclopropane 10i $(90 \%)$ (Table 1, entry 8). The rearrangement of the diastereomeric mixture of 9j/9j' (syn/anti = 90:10) also proceeded efficiently, but provided a mixture of the corresponding alkylidenecyclopropane diastereomers $\mathbf{1 0 j}$ and $\mathbf{1 0 j}$ ' in a 65:35 ratio $(81 \%)$ (Table 1 , entry 9$)$. A mixture of $\mathbf{9 j} / \mathbf{9 j}$ ' with an inverted diastereomeric ratio $(\mathbf{9} \mathbf{j} / \mathbf{9} \mathbf{j} '=23: 77)$ was also prepared (by oxidation of the mixture of $\mathbf{9 j} / \mathbf{9} \mathbf{j}$ ' and reduction of the resulting ketone with DIBAL-H) and involved in the gold-catalyzed rearrangement. The diastereomeric alkylidenecyclopropanes $\mathbf{1 0 j} / \mathbf{1 0 j}$ ' were then formed in a 43:57 ratio (77\%) (Table 1 , entry 10$)$.

The erosion of the diastereomeric ratio in the goldcatalyzed rearrangement of epimeric substrates $\mathbf{9 j} / \mathbf{9 j}$ ' seems to point toward a non-stereospecific rearrangement process. Therefore, the behaviour of the enantioenriched substrate $9 \mathbf{a}$ was investigated to gain further insight into the mechanism.
Table 1 Gold-catalyzed rearrangement of substrates $\mathbf{9 b}-\mathbf{9 j} / \mathbf{9 j}$;

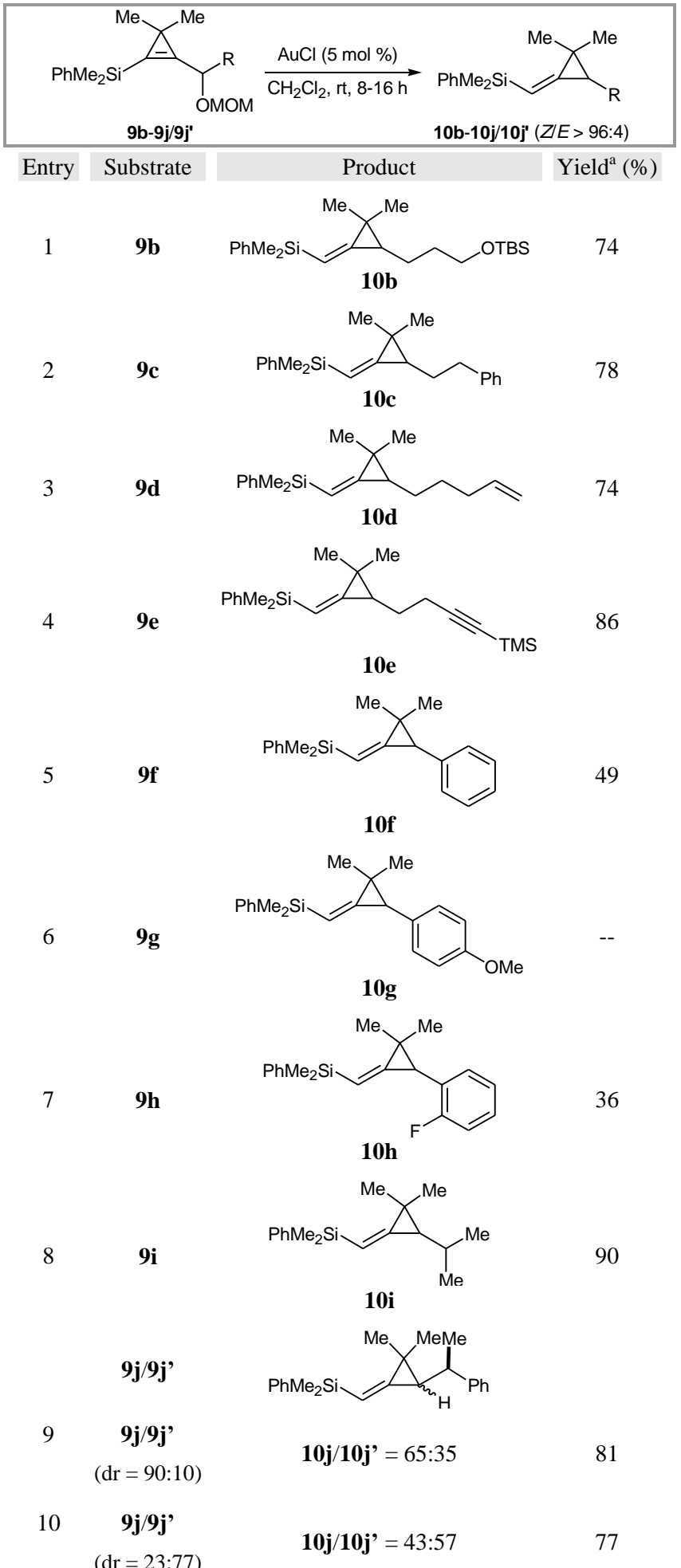

${ }^{a}$ Isolated yield of analytically pure material.

Considering the similarities between cyclopropenes and alkynes, ${ }^{25}$ we surmised that the ruthenium(II)catalyzed enantioselective hydrogenation transfer ${ }^{26}$ of silylcyclopropenyl ketones could provide access to optically enriched silylcyclopropenyl carbinols. Effectively, cyclopropenyl ketone 11, prepared by oxidation of the racemic alcohol $( \pm)-8 \mathbf{a}$ using DessMartin periodinane (DMP), successfully underwent 
chemoselective hydrogenation transfer in isopropanol in the presence of Noyori's catalyst $(R, R)-[\mathrm{Ru}]-\mathrm{I}^{26}$ $(3 \times 6 \mathrm{~mol} \%)\left(\mathrm{rt}\right.$ to $\left.40{ }^{\circ} \mathrm{C}\right)$. Although the conditions were not optimized, the optically active silylcyclopropenyl carbinol $(R)-8 \mathbf{a}$ was obtained in good yield (74\%) and with a decent enantiomeric excess $(e e=75 \%)$. The absolute configuration of this latter alcohol was not determined unambiguously but assigned by analogy with the known face-selectivity of the hydrogenation transfer of acetylenic ketones, considering the $\pi$-donating character of a cyclopropene. $^{27}$ The enantioenriched cyclopropenylmethyl ether $(R)-9 \mathbf{a}$ was then prepared from $(R)-\mathbf{8 a}$ and involved in the gold-catalyzed rearrangement. The formation of racemic (silylmethylene)cyclopropane $( \pm)-10 a(95 \%)$ confirmed the non-stereospecific character of the gold-catalyzed rearrangement (Scheme 8).

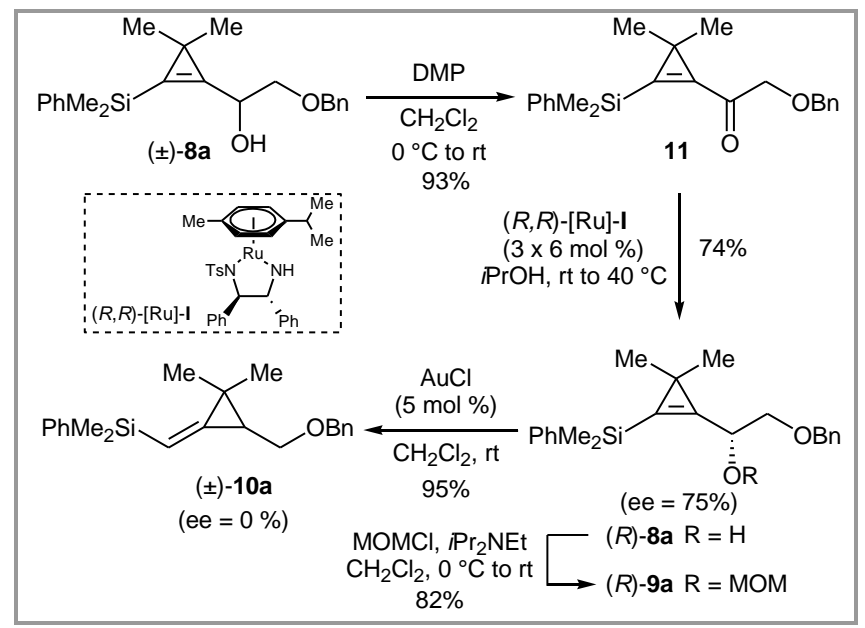

Scheme 8 Preparation and gold-catalyzed rearrangement of optically active MOM ether $(R)-9 \mathbf{a}$.

After regioselective ring-opening of cyclopropenes $\mathbf{K}$ and 1,5-hydride transfer to the $\alpha$-(dimethylphenylsilyl) gold carbenoids $\mathbf{M}$, the rearrangement of the resulting allylic organogold species $\mathbf{N}$ into (silylmethylene)cyclopropanes $\mathbf{L}$ likely involves the dissociation of the $\mathrm{C} 4-\mathrm{O}$ bond with elimination of methyl formate to a large extent, if not completely as in the case of substrate $(R)-9 \mathbf{a}$ for which complete racemization occurs. The $\mathrm{C} 3-\mathrm{C} 4$ bond would then be created by $2 \pi$-electrocyclization of the allylic cation $\mathbf{O}$ followed by formation of the $\mathrm{C} 1=\mathrm{C} 2$ double bond by elimination of gold. The stereoselectivity of this latter step is difficult to explain at this stage but the isopropylidene substituent is presumably acting as a key element for the control of the conformation around the $\mathrm{C} 1-\mathrm{C} 2$ and $\mathrm{C} 1-\mathrm{C} 4$ in the cationic intermediate $\mathbf{O}$ (Scheme 9). ${ }^{28}$

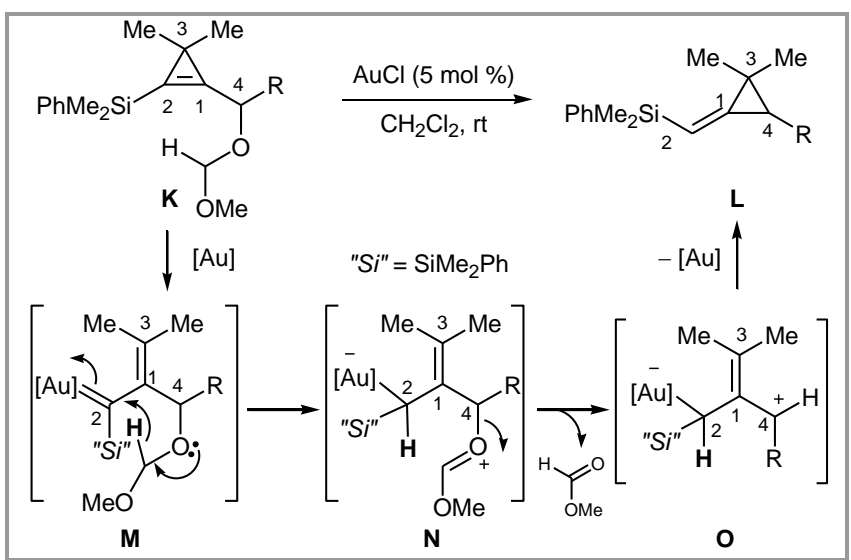

Scheme 9 Plausible mechanism accounting for the formation of (silylmethylene)cyclopropane $\mathbf{2}$ from $\mathbf{1 a}$ and $\mathbf{1 b}$.

The reactivity of the (silylmethylene)cyclopropanes $\mathbf{L}$ produced by the gold-catalyzed rearrangement of MOM ethers $\mathbf{K}$ is still under investigation. We have showed so far that the diastereoselective hydrogenation of the exocyclic alkene could be achieved $\left(\mathrm{H}_{2}\right.$, cat. $\mathrm{Pd} / \mathrm{C}$, EtOAc, rt) (on the face opposite to the silyloxypropyl chain) to afford the cis-disusbtituted cyclopropane 12 (88\%) (Scheme 10).

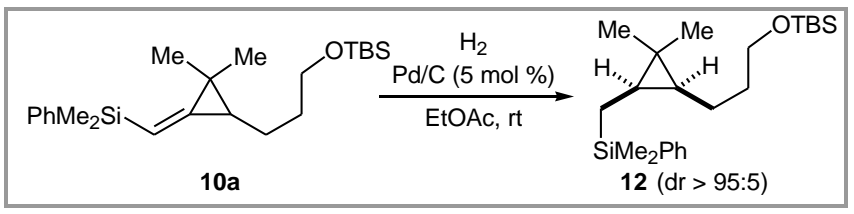

Scheme 10 Diastereoselective hydrogenation of 10a.

In summary, we have disclosed a new transition metal-catalyzed process involving cyclopropenyl carbinol derivatives that complements the transformations in which these latter substrates have been involved so far. In the presence of gold chloride, MOM ethers derived from (dimethylphenylsilyl)cyclopropenyl carbinols undergo rearrangement to (dimethylphenylsilylmethylene)cyclopropanes and methyl formate. We have provided evidence that the key steps of this rearrangement involve a regioselective ring-opening of the cyclopropene ring leading to an $\alpha$-silyl gold carbenoid and a 1,5-hydride transfer, which triggers subsequent elimination of methyl formate, a $2 \pi$-electrocyclization of the resulting allylic cation and elimination of the metal. Further investigation on the scope of this transformation as well as on the reactivity of the corresponding (silylmethylene)cyclopropane products are underway.

\section{Experimental Section}

Reactions involving air- and moisture-sensitive organometallic reagents were carried out under argon in flame-dried glassware with a magnetic stirring bar 
and sealed with a rubber septum. THF was distilled from sodium-benzophenone. $i \mathrm{Pr}_{2} \mathrm{NH}, i \mathrm{Pr}_{2} \mathrm{NEt}, \mathrm{CH}_{2} \mathrm{Cl}_{2}$ and $i \mathrm{PrOH}$ were distilled from $\mathrm{CaH}_{2}$. Reagents were obtained from commercial suppliers and used as received without further purification. Flash column chromatography was performed on silica gel (230-400 mesh). Infrared spectra were recorded with a Bruker TENSOR 27 instrument (IR-FT) with attenuated total reflectance (ATR). NMR spectra were recorded with a Bruker AVANCE 400 instrument. ${ }^{1} \mathrm{H}$ NMR spectra were recorded at $400 \mathrm{MHz}$ and data are reported as follows: chemical shift relative to tetramethylsilane, multiplicity, coupling constant, integration. ${ }^{13} \mathrm{C}$ NMR spectra were recorded at $100 \mathrm{MHz}$ and data are reported as follows: chemical shift referenced to the solvent signal ( $\delta 77.16 \mathrm{ppm}$ for $\mathrm{CDCl}_{3}$ ) and carbon environment (deduced from DEPT experiments). HRMS (ESI) were obtained with an orbitrap mass analyzer. Enantiomeric purities were determined by supercritical fluid chromatography (SFC) on a Minigram Berger SFC-Mettler Toledo apparatus equipped with a chiral stationary phase.

The preparation of silylcyclopropenes $\mathbf{1 a}, \mathbf{1 b}, \mathbf{1}$ 'b, 9b$\mathbf{9 j} / \mathbf{9 j}$ ' is detailed in the Supporting Information.

\section{Gold-Catalyzed Rearrangement of Cyclopropenes 1a, $1 \mathrm{~b}$ and 1 'b}

\section{(\{(1Z)-3-[(Benzyloxy)methyl]-2,2-dimethylcyclo- propylidene\}methyl)trimethylsilane (2).}

To a solution of silylcyclopropene $1 \mathrm{a}(52 \mathrm{mg}, 0.16$ mmol) in $\mathrm{CH}_{2} \mathrm{Cl}_{2}(3 \mathrm{~mL})$ at $\mathrm{rt}$, was added $\mathrm{AuCl}$ (1.8 mg, $0.0077 \mathrm{mmol}, 5 \mathrm{~mol} \%$ ). After $5 \mathrm{~h}$ stirring, the reaction mixture was filtered through Celite $\left(\mathrm{CH}_{2} \mathrm{Cl}_{2}\right)$. The filtrate was evaporated under reduced pressure and the crude material was analyzed by ${ }^{1} \mathrm{H}$ NMR spectroscopy which indicated the formation of $\mathbf{2}$ with high stereoselectivity $(Z / E>95: 5)$. After purification by flash column chromatography (petroleum ether/EtOAc, 98:2 to 96:4), $37 \mathrm{mg}$ (85\%) of 2 were isolated as a yellow oil. Compound $\mathbf{2}$ was also obtained by the gold-catalyzed rearrangement of silylcyclopropene 1b [Yield: $46 \mathrm{mg}$ (87\%)] and in this case benzaldehyde was detected by analysis of the crude material by ${ }^{1} \mathrm{H}$ NMR spectroscopy.

IR (neat): 1730, 1454, 1365, 1246, 1090, 1075, 862, $835,734,695 \mathrm{~cm}^{-1}$.

${ }^{1} \mathrm{H}$ NMR (400 MHz, $\left.\mathrm{C}_{6} \mathrm{D}_{6}\right): \delta=7.43($ br d, $J=7.4 \mathrm{~Hz}$, 2H), 7.31-7.27 (m, 2H), $7.20(\mathrm{~m}, 1 \mathrm{H}), 6.10(\mathrm{~d}, J=$ $1.8 \mathrm{~Hz}, 1 \mathrm{H}), 4.50$ (d, AB syst, $J=12.2 \mathrm{~Hz}, 1 \mathrm{H}), 4.45$ (d, AB syst, $J=12.2 \mathrm{~Hz}, 1 \mathrm{H}), 3.70(\mathrm{dd}, J=10.5$, $5.7 \mathrm{~Hz}, 1 \mathrm{H}), 3.42(\mathrm{dd}, J=10.5,9.1 \mathrm{~Hz}, 1 \mathrm{H}), 1.66$ (ddd, $J=9.1,5.7,1.8 \mathrm{~Hz}, 1 \mathrm{H}), 1.29$ (s, 6H), 0.25 (s, 9H).

Signals observed at $6.13(\mathrm{~d}, J=2.3 \mathrm{~Hz}, 1 \mathrm{H})$ and 3.85 $(\mathrm{dd}, J=10.3,5.3 \mathrm{~Hz}, 1 \mathrm{H}), 1.78$ (ddd, $J=9.7,5.3,2.3$ $\mathrm{Hz}, 1 \mathrm{H})$ were tentatively assigned to the $(Z)$ geometric isomer $(\mathrm{dr}>95: 5)$.
${ }^{13} \mathrm{C} \mathrm{NMR}\left(100 \mathrm{MHz}, \mathrm{CDCl}_{3}\right): \delta=154.6(\mathrm{C}), 138.8$ (C), $128.5(2 \times \mathrm{CH}), 127.8(2 \times \mathrm{CH}), 127.6(\mathrm{CH})$, $116.9(\mathrm{CH}), 72.6\left(\mathrm{CH}_{2}\right), 69.5\left(\mathrm{CH}_{2}\right), 27.2\left(\mathrm{CH}_{3}\right), 26.5$ (CH), $20.9(\mathrm{C}), 19.5\left(\mathrm{CH}_{3}\right),-0.5\left(3 \times \mathrm{CH}_{3}\right)$.

HRMS (ESI): $m / z$ calcd for $\mathrm{C}_{17} \mathrm{H}_{26} \mathrm{ONaSi}\left[\mathrm{M}+\mathrm{Na}^{+}\right]$: 297.16466; found: 297.16451.

\section{(\{(1Z)-3-[(Benzyloxy)methyl]-2,2-dimethylcyclo- propylidene $\}\left({ }^{2} \mathbf{H}\right)$ methyl $\}$ trimethylsilane (2').}

Prepared by gold-catalyzed rearrangement of $\mathbf{1}$ 'b and purified by flash column chromatography (petroleum ether/EtOAc, 98:2 to 96:4).

Yield: $60 \mathrm{mg}(89 \%)$; colorless oil.

IR (neat): 1726, 1454, 1365, 1245, 1090, 1051, 1028, $834,755,734,695 \mathrm{~cm}^{-1}$.

${ }^{1} \mathrm{H}$ NMR (400 MHz, $\left.\mathrm{CDCl}_{3}\right): \delta=7.37-7.27(\mathrm{~m}, 5 \mathrm{H})$, $4.56(\mathrm{~d}, \mathrm{AB}$ syst, $J=12.0 \mathrm{~Hz}, 1 \mathrm{H}), 4.51$ (d, AB syst, $J=12.0 \mathrm{~Hz}, 1 \mathrm{H}), 3.64(\mathrm{dd}, J=10.7,5.6 \mathrm{~Hz}, 1 \mathrm{H}), 3.34$ $(\mathrm{dd}, J=10.6,9.2 \mathrm{~Hz}, 1 \mathrm{H}), 1.47(\mathrm{dd}, J=9.1,5.6 \mathrm{~Hz}$, $1 \mathrm{H}), 1.24$ (s, 3H), 1.17 (s, 3H), 0.09 (s, 9H).

${ }^{13} \mathrm{C}$ NMR $\left(100 \mathrm{MHz}, \mathrm{CDCl}_{3}\right): \delta=154.5(\mathrm{C}), 138.8$ (C), $128.5(2 \times \mathrm{CH}), 127.9(2 \times \mathrm{CH}), 127.6(\mathrm{CH})$, $116.5\left(\mathrm{CD}, \mathrm{t},{ }^{1} J_{C-D}=21.2 \mathrm{~Hz}\right), 72.6\left(\mathrm{CH}_{2}\right), 69.5\left(\mathrm{CH}_{2}\right)$, $27.1\left(\mathrm{CH}_{3}\right), 26.5(\mathrm{CH}), 20.8(\mathrm{C}), 19.5\left(\mathrm{CH}_{3}\right),-0.5$ $\left(3 \times \mathrm{CH}_{3}\right)$.

HRMS (ESI): $m / z$ calcd for $\mathrm{C}_{17} \mathrm{H}_{25} \mathrm{DONaSi}$ $\left[\mathrm{M}+\mathrm{Na}^{+}\right]$: 298.17092; found: 298.17079 .

\section{Preparation of (silylcyclopropenyl)methyl MOM ethers (Representative Procedure for 9a)}

\section{2-(Benzyloxy)-1-[2-(dimethylphenylsilyl)- 3,3-dimethylcycloprop-1-en-1-yl] ethan-1-ol (8a).}

To a solution of cyclopropenylsilane 6 (1.29 g, 6.39 mmol, 1.6 equiv) in THF $(20 \mathrm{~mL})$ at $-78{ }^{\circ} \mathrm{C}$ was added dropwise $n$-BuLi $(2.4 \mathrm{~mL}, 2.5 \mathrm{M}$ solution in hexanes, $6.0 \mathrm{mmol}, 1.5$ equiv). After $1 \mathrm{~h}$ stirring from $-78{ }^{\circ} \mathrm{C}$ to $-10{ }^{\circ} \mathrm{C}$, the reaction mixture was cooled to $-50{ }^{\circ} \mathrm{C}$ and benzyloxyacetaldehyde $(561 \mu \mathrm{L}, 4.00$ mmol) was added. The reaction mixture was allowed to warm to $-10{ }^{\circ} \mathrm{C}$ within $1 \mathrm{~h}$, stirred for a further $1 \mathrm{~h}$ at that temperature and then hydrolyzed with a saturated aqueous solution of $\mathrm{NH}_{4} \mathrm{Cl}$. The layers were separated and the aqueous phase was extracted with $\mathrm{Et}_{2} \mathrm{O}$. The combined organic phases were washed with brine, dried over $\mathrm{MgSO}_{4}$, filtered and concentrated under reduced pressure. Purification of the crude material by flash column chromatography (petroleum ether/ $\mathrm{Et}_{2} \mathrm{O}, 100: 0$ to $\left.93: 7\right)$ afforded $273 \mathrm{mg}(70 \%)$ of alcohol 8a as a yellow oil.

IR (neat): 3448 (br), 1777, 1454, 1428, 1363, 1248, $1113,818,778,731,697,655 \mathrm{~cm}^{-1}$.

${ }^{1} \mathrm{H}$ NMR (400 MHz, $\left.\mathrm{CDCl}_{3}\right): \delta=7.58-7.55$ (m, 2H), 7.40-7.27 (m, 8H), 4.91 (m, 1H), 4.56 (d, AB syst, $J=$ $12.1 \mathrm{~Hz}, 1 \mathrm{H}), 4.53(\mathrm{~d}, \mathrm{AB}$ syst, $J=12.1 \mathrm{~Hz}, 1 \mathrm{H}), 3.63$ $(\mathrm{dd}, J=9.6,3.5 \mathrm{~Hz}, 1 \mathrm{H}), 3.49(\mathrm{dd}, J=9.6,6.9 \mathrm{~Hz}$, 
1H), $2.24(\mathrm{~d}, J=5.1 \mathrm{~Hz}, 1 \mathrm{H}, \mathrm{OH}), 1.18(\mathrm{~s}, 3 \mathrm{H}), 1.17$ (s, 3H), 0.424 (s, 3H), 0.419 (s, 3H).

${ }^{13} \mathrm{C}$ NMR $\left(100 \mathrm{MHz}, \mathrm{CDCl}_{3}\right): \delta=149.0(\mathrm{C}), 138.1$ (C), $138.0(\mathrm{C}), 133.8(2 \times \mathrm{CH}), 129.4(\mathrm{CH}), 128.6$ $(2 \times \mathrm{CH}), 128.0(2 \times \mathrm{CH}), 127.9(3 \times \mathrm{CH}), 124.6(\mathrm{C})$, $73.6\left(\mathrm{CH}_{2}\right), 73.2\left(\mathrm{CH}_{2}\right), 69.8(\mathrm{CH}), 27.93\left(\mathrm{CH}_{3}\right)$, $27.85\left(\mathrm{CH}_{3}\right), 22.6(\mathrm{C}),-1.6\left(2 \times \mathrm{CH}_{3}\right)$.

HRMS (ESI): $m / z$ calcd for $\mathrm{C}_{22} \mathrm{H}_{28} \mathrm{O}_{2} \mathrm{SiNa}\left[\mathrm{M}+\mathrm{Na}^{+}\right]$: 375.17508; found: 375.17532 .

\section{\{2-[2-(Benzyloxy)-1-(methoxymethoxy)ethyl]-} 3,3-dimethylcycloprop-1-en-1-yl dimethylphenylsilane (9a).

To a solution of alcohol 8a (507 $\mathrm{mg}, 1.44 \mathrm{mmol})$ in $\mathrm{CH}_{2} \mathrm{Cl}_{2}(15 \mathrm{~mL})$ at $0{ }^{\circ} \mathrm{C}$ were successively added $i \operatorname{Pr}_{2} \mathrm{NEt}(1.25 \mathrm{~mL}, 7.18 \mathrm{mmol}, 5$ equiv) and $\mathrm{MOMCl}$ $(0.55 \mathrm{~mL}, 7.2 \mathrm{mmol}, 5$ equiv) dropwise. After stirring for $12 \mathrm{~h}$ at $\mathrm{rt}$, the reaction mixture was hydrolyzed with a saturated aqueous solution of $\mathrm{NH}_{4} \mathrm{Cl}$. The layers were separated and the aqueous phase was extracted with $\mathrm{CH}_{2} \mathrm{Cl}_{2}$. The combined organic phases were washed with brine, dried over $\mathrm{MgSO}_{4}$, filtered and concentrated under reduced pressure. The crude material was purified by flash column chromatography (petroleum ether $/ \mathrm{Et}_{2} \mathrm{O}, 90: 10$ ) to afford $508 \mathrm{mg}$ (89\%) of $\mathbf{9 a}$ as a yellow oil.

IR (neat): 1776, 1364, 1248, 1153, 1113, 1028, 919, $817,778,731,697,655 \mathrm{~cm}^{-1}$.

${ }^{1} \mathrm{H}$ NMR $\left(400 \mathrm{MHz}, \mathrm{CDCl}_{3}\right): \delta=7.56-7.53(\mathrm{~m}, 2 \mathrm{H})$, 7.36-7.25 (m, 8H), 4.98 (apparent t, $J=5.6 \mathrm{~Hz}, 1 \mathrm{H})$, 4.72 (d, AB syst, $J=6.6 \mathrm{~Hz}, 1 \mathrm{H}), 4.61$ (d, AB syst, $J=6.6 \mathrm{~Hz}, 1 \mathrm{H}), 4.57(\mathrm{~d}, \mathrm{AB}$ syst, $J=12.0 \mathrm{~Hz}, 1 \mathrm{H})$, $4.53(\mathrm{~d}, \mathrm{AB}$ syst, $J=12.0 \mathrm{~Hz}, 1 \mathrm{H}), 3.62(\mathrm{~d}, J=$ $5.6 \mathrm{~Hz}, 2 \mathrm{H}), 3.38$ (s, 3H), 1.153 (s, 3H), 1.148 (s, 3H), $0.41(\mathrm{~s}, 6 \mathrm{H})$.

${ }^{13} \mathrm{C}$ NMR $\left(100 \mathrm{MHz}, \mathrm{CDCl}_{3}\right): \delta=146.9(\mathrm{C}), 138.3$ (C), $137.9(\mathrm{C}), 133.9(2 \times \mathrm{CH}), 129.3(\mathrm{CH}), 128.4$ $(2 \times \mathrm{CH}), 127.9(3 \times \mathrm{CH}), 127.7(2 \times \mathrm{CH}), 125.3(\mathrm{C})$, $94.7\left(\mathrm{CH}_{2}\right), 73.4\left(\mathrm{CH}_{2}\right), 72.5(\mathrm{CH}), 72.2\left(\mathrm{CH}_{2}\right), 55.5$ $\left(\mathrm{CH}_{3}\right), 27.92\left(\mathrm{CH}_{3}\right), 27.90\left(\mathrm{CH}_{3}\right), 21.6(\mathrm{C}),-1.6$ $\left(2 \times \mathrm{CH}_{3}\right)$.

HRMS (ESI): $\mathrm{m} / z$ calcd for $\mathrm{C}_{24} \mathrm{H}_{32} \mathrm{O}_{3} \mathrm{SiNa}\left[\mathrm{M}+\mathrm{Na}^{+}\right]$: 419.20129; found: 419.20175 .

\section{Gold-Catalyzed Rearrangement of $9 \mathrm{a}-9 \mathrm{j} / 9 \mathrm{j}$; Representative Procedure}

To a solution of silylcyclopropene 9a (400 mg, 1.01 mmol) in $\mathrm{CH}_{2} \mathrm{Cl}_{2}$ at $\mathrm{rt}$, was added $\mathrm{AuCl}(11.7 \mathrm{mg}$, $0.0503 \mathrm{mmol}, 5 \mathrm{~mol} \%$ ). After $8 \mathrm{~h}$ stirring, the reaction mixture was filtered through Celite $\left(\mathrm{CH}_{2} \mathrm{Cl}_{2}\right)$. The filtrate was evaporated under reduced pressure and the crude material was analyzed by ${ }^{1} \mathrm{H}$ NMR spectroscopy which indicated the formation of 10a as a single detectable geometric isomer $(Z / E>96: 4)$. After purification by flash column chromatography (petroleum ether/Et $\left.{ }_{2} \mathrm{O}: 95: 5\right), 292 \mathrm{mg}(86 \%)$ of 10a were isolated as a yellow oil.

\{[(1Z)-3-(Benzyloxymethyl)-2,2-dimethylcyclopropylidene]methyl \} dimethylphenylsilane (10a).

IR (neat): 1726, 1454, 1427, 1365, 1246, 1113, 1089, $1074,840,827,730,696 \mathrm{~cm}^{-1}$.

${ }^{1} \mathrm{H}$ NMR $\left(400 \mathrm{MHz}, \mathrm{CDCl}_{3}\right): \delta=7.55-7.50(\mathrm{~m}, 2 \mathrm{H})$, 7.36-7.27 (m, 8H), $5.99(\mathrm{~d}, J=1.7 \mathrm{~Hz}, 1 \mathrm{H}), 4.55(\mathrm{~d}$, AB syst, $J=12.0 \mathrm{~Hz}, 1 \mathrm{H}), 4.50(\mathrm{~d}, \mathrm{AB}$ syst, $J=12.0$ $\mathrm{Hz}, 1 \mathrm{H}), 3.64(\mathrm{dd}, J=10.6,5.7 \mathrm{~Hz}, 1 \mathrm{H}), 3.35$ (dd, $J=$ $10.6,9.1 \mathrm{~Hz}, 1 \mathrm{H}), 1.50$ (ddd, $J=9.1,5.7,1.7 \mathrm{~Hz}, 1 \mathrm{H})$, $1.15(\mathrm{~s}, 3 \mathrm{H}), 1.08(\mathrm{~s}, 3 \mathrm{H}), 0.36(\mathrm{~s}, 6 \mathrm{H})$.

${ }^{13} \mathrm{C}$ NMR $\left(100 \mathrm{MHz}, \mathrm{CDCl}_{3}\right): \delta=156.6(\mathrm{C}), 139.4$ (C), $138.7(\mathrm{C}), 134.0(2 \times \mathrm{CH}), 129.0(\mathrm{CH}), 128.5$ $(2 \times \mathrm{CH}), 127.9(4 \times \mathrm{CH}), 127.7(\mathrm{CH}), 115.0(\mathrm{CH})$, $72.6\left(\mathrm{CH}_{2}\right), 69.5\left(\mathrm{CH}_{2}\right), 27.4(\mathrm{CH}), 26.3\left(\mathrm{CH}_{3}\right), 21.1$ (C), $19.3\left(\mathrm{CH}_{3}\right),-1.8\left(2 \times \mathrm{CH}_{3}\right)$.

HRMS (ESI): $m / z$ calcd for $\mathrm{C}_{22} \mathrm{H}_{28} \mathrm{OSiNa}\left[\mathrm{M}+\mathrm{Na}^{+}\right]$: 359.18016.; found: 359.18051 .

tert-Butyl(\{3-[(3Z)-3-[(dimethylphenylsilyl)methylidene]-2,2-dimethylcyclopropyl]\}propoxy)dimethylsilane (10b).

Purified by flash column chromatography (petroleum ether/ $\left.\mathrm{Et}_{2} \mathrm{O}, 98: 2\right)$.

Yield: $144 \mathrm{mg}$ (74\%); yellow oil.

IR (neat): 1723, 1471, 1462, 1428, 1247, 1111, 1098, $832,773,728,698,663 \mathrm{~cm}^{-1}$.

${ }^{1} \mathrm{H}$ NMR $\left(400 \mathrm{MHz}, \mathrm{CDCl}_{3}\right): \delta=7.56-7.51(\mathrm{~m}, 2 \mathrm{H})$, $7.36-7.33(\mathrm{~m}, 3 \mathrm{H}), 5.95(\mathrm{~d}, J=1.5 \mathrm{~Hz}, 1 \mathrm{H}), 3.67-$ $3.58(\mathrm{~m}, 2 \mathrm{H}), 1.67-1.60(\mathrm{~m}, 2 \mathrm{H}), 1.48-1.32(\mathrm{~m}, 2 \mathrm{H})$, $1.10(\mathrm{~s}, 3 \mathrm{H}), 1.05-1.01(\mathrm{~m}, 1 \mathrm{H}), 1.01(\mathrm{~s}, 3 \mathrm{H}), 0.89(\mathrm{~s}$, $9 \mathrm{H}), 0.35$ (s, 6H), $0.05(\mathrm{~s}, 6 \mathrm{H})$.

${ }^{13} \mathrm{C}$ NMR $\left(100 \mathrm{MHz}, \mathrm{CDCl}_{3}\right): \delta=160.9(\mathrm{C}), 139.9$ (C), $134.0(2 \times \mathrm{CH}), 128.9(\mathrm{CH}), 127.8(2 \times \mathrm{CH})$, $112.9(\mathrm{CH}), 63.2\left(\mathrm{CH}_{2}\right), 33.3\left(\mathrm{CH}_{2}\right), 27.4\left(\mathrm{CH}_{3}\right), 26.7$ $\left(\mathrm{CH}_{3}\right), 26.1\left(3 \times \mathrm{CH}_{3}\right), 24.7\left(\mathrm{CH}_{2}\right), 20.1(\mathrm{C}), 19.2$ $(\mathrm{CH}), 18.5(\mathrm{C}),-1.7\left(2 \times \mathrm{CH}_{3}\right),-5.1\left(2 \times \mathrm{CH}_{3}\right)$.

HRMS (ESI): $\mathrm{m} / z$ calcd for $\mathrm{C}_{23} \mathrm{H}_{41} \mathrm{OSi}_{2}\left[\mathrm{M}+\mathrm{H}^{+}\right]$: 389.26905; found: 389.26915 .

\{[(1Z)-2,2-Dimethyl-3-(2-phenylethyl)cyclopropylidene]methyl\}dimethylphenylsilane (10c).

Purified by flash column chromatography (petroleum ether/ $\left.\mathrm{Et}_{2} \mathrm{O}, 98: 2\right)$.

Yield: $66 \mathrm{mg}$ (78\%); colorless oil.

IR (neat): 1722, 1495, 1454, 1427, 1367, 1245, 1113, $841,826,788,746,729,697 \mathrm{~cm}^{-1}$.

${ }^{1} \mathrm{H}$ NMR $\left(400 \mathrm{MHz}, \mathrm{CDCl}_{3}\right): \delta=7.57-7.54(\mathrm{~m}, 2 \mathrm{H})$, 7.39-7.35 (m, 3H), 7.32-7.27 (m, 2H), 7.23-7.18 (m, $3 \mathrm{H}), 5.91$ (br s, 1H), 2.74 (br t, $J=7.5 \mathrm{~Hz}, 2 \mathrm{H}), 1.75-$ 
$1.68(\mathrm{~m}, 2 \mathrm{H}), 1.11(\mathrm{~s}, 3 \mathrm{H}), 1.11-1.07(\mathrm{~m}, 1 \mathrm{H}), 0.99(\mathrm{~s}$, $3 \mathrm{H}), 0.37$ (s, 6H).

${ }^{13} \mathrm{C}$ NMR $\left(100 \mathrm{MHz}, \mathrm{CDCl}_{3}\right): \delta=160.5(\mathrm{C}), 142.6$ (C), $139.8(\mathrm{C}), 134.0(2 \times \mathrm{CH}), 128.9(\mathrm{CH}), 128.7$ $(2 \times \mathrm{CH}), 128.4(2 \times \mathrm{CH}), 127.8(2 \times \mathrm{CH}), 125.8$ $(\mathrm{CH}), 113.1(\mathrm{CH}), 36.4\left(\mathrm{CH}_{2}\right), 30.6\left(\mathrm{CH}_{2}\right), 27.2(\mathrm{CH})$, $26.6\left(\mathrm{CH}_{3}\right), 20.3(\mathrm{C}), 19.2\left(\mathrm{CH}_{3}\right),-1.7\left(2 \times \mathrm{CH}_{3}\right)$.

HRMS (ESI): $m / z$ calcd for $\mathrm{C}_{22} \mathrm{H}_{28} \mathrm{SiNa}\left[\mathrm{M}+\mathrm{Na}^{+}\right]$: 343.18525; found: 343.18531 .

\{[(1Z)-2,2-Dimethyl-3-(pent-4-en-1-yl)cyclopropylidene]methyl \}dimethylphenylsilane (10d).

Purified by flash column chromatography (petroleum ether/ $\left.\mathrm{Et}_{2} \mathrm{O}, 95: 5\right)$.

Yield: $61 \mathrm{mg}$ (74\%); colorless oil.

IR (neat): 1722, 1641, 1428, 1368, 1246, 1113, 910, $840,825,787,729,698 \mathrm{~cm}^{-1}$.

${ }^{1} \mathrm{H}$ NMR $\left(400 \mathrm{MHz}, \mathrm{CDCl}_{3}\right): \delta=7.59-7.55(\mathrm{~m}, 2 \mathrm{H})$, $7.39-7.35(\mathrm{~m}, 3 \mathrm{H}), 5.99(\mathrm{~d}, J=1.0 \mathrm{~Hz}, 1 \mathrm{H}), 5.85(\mathrm{ddt}$, $J=17.0,10.2,6.6 \mathrm{~Hz}, 1 \mathrm{H}), 5.04(\mathrm{dm}$, apparent br d, $J=17.0 \mathrm{~Hz}, 1 \mathrm{H}), 4.97(\mathrm{dm}$, apparent br d, $J=$ $10.5 \mathrm{~Hz}, 1 \mathrm{H}), 2.14-2.08(\mathrm{~m}, 2 \mathrm{H}), 1.58-1.33(\mathrm{~m}, 4 \mathrm{H})$, $1.13(\mathrm{~s}, 3 \mathrm{H}), 1.08-1.06(\mathrm{~m}, 1 \mathrm{H}), 1.06(\mathrm{~s}, 3 \mathrm{H}), 0.39$ (s, $6 \mathrm{H})$.

${ }^{13} \mathrm{C}$ NMR $\left(100 \mathrm{MHz}, \mathrm{CDCl}_{3}\right): \delta=161.0(\mathrm{C}), 139.9$ (C), $139.2(\mathrm{CH}), 134.0(2 \times \mathrm{CH}), 128.9(\mathrm{CH}), 127.8$ $(2 \times \mathrm{CH}), 114.5\left(\mathrm{CH}_{2}\right), 112.0(\mathrm{CH}), 33.8\left(\mathrm{CH}_{2}\right), 29.4$ $\left(\mathrm{CH}_{2}\right), 28.0\left(\mathrm{CH}_{2}\right), 27.6(\mathrm{CH}), 26.7\left(\mathrm{CH}_{3}\right), 20.1(\mathrm{C})$, $19.3\left(\mathrm{CH}_{3}\right),-1.7\left(2 \times \mathrm{CH}_{3}\right)$.

\{4-[(3Z)-3-\{[dimethylphenylsilyl]methylidene\}-2,2dimethylcyclopropyl]but-1-yn-1-yl\}trimethylsilane (10e).

Purified by flash column chromatography (petroleum ether/Et ${ }_{2} \mathrm{O}, 90: 10$ ).

Yield: $73 \mathrm{mg}(86 \%)$; colorless oil.

IR (neat): 2174, 1723, 1247, 1113, 1047, 838, 759, $729,698,638 \mathrm{~cm}^{-1}$.

${ }^{1} \mathrm{H}$ NMR $\left(400 \mathrm{MHz}, \mathrm{CDCl}_{3}\right): \delta=7.57-7.53(\mathrm{~m}, 2 \mathrm{H})$, $7.38-7.35(\mathrm{~m}, 3 \mathrm{H}), 6.02(\mathrm{~d}, J=1.7 \mathrm{~Hz}, 1 \mathrm{H}), 2.36-$ $2.32(\mathrm{~m}, 2 \mathrm{H}), 1.70-1.56(\mathrm{~m}, 2 \mathrm{H}), 1.17-1.13(\mathrm{~m}, 1 \mathrm{H})$, $1.13(\mathrm{~s}, 3 \mathrm{H}), 1.05$ (s, 3H), 0.38 (s, 6H), 0.17 (s, 9H).

${ }^{13} \mathrm{C}$ NMR $\left(100 \mathrm{MHz}, \mathrm{CDCl}_{3}\right): \delta=159.9(\mathrm{C}), 139.7$ (C), $134.0(2 \times \mathrm{CH}), 129.0(\mathrm{CH}), 127.8(2 \times \mathrm{CH})$, $113.6(\mathrm{CH}), 107.6(\mathrm{C}), 84.2(\mathrm{C}), 27.9\left(\mathrm{CH}_{2}\right), 27.0$ $(\mathrm{CH}), 26.5\left(\mathrm{CH}_{3}\right), 20.5(\mathrm{C}), 20.5\left(\mathrm{CH}_{2}\right), 19.4\left(\mathrm{CH}_{3}\right)$, $0.3\left(3 \times \mathrm{CH}_{3}\right),-1.7\left(2 \times \mathrm{CH}_{3}\right)$.

HRMS (ESI): $m / z$ calcd for $\mathrm{C}_{21} \mathrm{H}_{32} \mathrm{Si}_{2} \mathrm{Na}\left[\mathrm{M}+\mathrm{Na}^{+}\right]$: 363.19347; found: 363.19347 .

\{[(1Z)-2,2-Dimethyl-3-phenylcyclopropylidene]methyl\}dimethylphenylsilane (10f).

Purified by flash column chromatography (toluene).
Yield: $20 \mathrm{mg}$ (49\%); yellow oil.

IR (neat): 1733, 1601, 1494, 1449, 1427, 1246, 1113, 964, 839, 816, 793, 730, $697 \mathrm{~cm}^{-1}$.

${ }^{1} \mathrm{H}$ NMR $\left(400 \mathrm{MHz}, \mathrm{CDCl}_{3}\right): \delta=7.62-7.59(\mathrm{~m}, 2 \mathrm{H})$, 7.39-7.37 (m, 3H), 7.28-7.25 (m, 2H), 7.19-7.16 (m, $3 \mathrm{H}), 6.29(\mathrm{~d}, J=1.6 \mathrm{~Hz}, 1 \mathrm{H}), 2.41(\mathrm{~d}, J=1.6 \mathrm{~Hz}$, $1 \mathrm{H}), 1.28$ (s, 3H), 0.79 (s, 3H), 0.44 (s, 6H).

${ }^{13} \mathrm{C}$ NMR $\left(100 \mathrm{MHz}, \mathrm{CDCl}_{3}\right): \delta=156.9(\mathrm{C}), 139.4$ (C), 138.7 (C), $134.0(2 \times \mathrm{CH}), 129.13(2 \times \mathrm{CH})$, $129.10(\mathrm{CH}), 128.1(2 \times \mathrm{CH}), 127.9(2 \times \mathrm{CH}), 125.9$ $(\mathrm{CH}), 117.1(\mathrm{CH}), 32.6(\mathrm{CH}), 26.7\left(\mathrm{CH}_{3}\right), 24.5(\mathrm{C})$, $19.1\left(\mathrm{CH}_{3}\right),-1.6\left(\mathrm{CH}_{3}\right),-1.7\left(\mathrm{CH}_{3}\right)$.

\{[(1Z)-3-(2-Fluorophenyl)-2,2-dimethylcyclopropylidene]methyl $\}$ dimethylphenylsilane $(10 \mathrm{~h})$.

Purified by flash column chromatography (petroleum ether/Et $\left.{ }_{2} \mathrm{O}, 90: 10\right)$.

Yield: $30 \mathrm{mg}$ (36\%); colorless oil.

IR (neat): 1732, 1581, 1489, 1454, 1246, 1220, 1234, $1113,1098,965,829,814,789,753,730,698 \mathrm{~cm}^{-1}$.

${ }^{1} \mathrm{H}$ NMR $\left(400 \mathrm{MHz}, \mathrm{CDCl}_{3}\right): \delta=7.61-7.57(\mathrm{~m}, 2 \mathrm{H})$, 7.39-7.36 (m, 3H), 7.18-7.13 (m, 1H), $7.08(\mathrm{~m}, 1 \mathrm{H})$, 7.04-6.99 (m, 2H), $6.32(\mathrm{~d}, J=1.8 \mathrm{~Hz}, 1 \mathrm{H}), 2.45(\mathrm{~m}$, apparent br s, 1H), $1.31(\mathrm{~s}, 3 \mathrm{H}), 0.78(\mathrm{~s}, 3 \mathrm{H}), 0.43(\mathrm{~s}$, $6 \mathrm{H})$.

${ }^{13} \mathrm{C} \mathrm{NMR}\left(100 \mathrm{MHz}, \mathrm{CDCl}_{3}\right): \delta=163.2\left(\mathrm{C},{ }^{1} J_{\mathrm{C}-F}=\right.$ $\left.245.3 \mathrm{~Hz}, \mathrm{C}_{7}\right), 155.6(\mathrm{C}), 139.3(\mathrm{C}), 134.0(2 \times \mathrm{CH})$, $129.9\left(\mathrm{CH},{ }^{3} J_{C-F}=4.2 \mathrm{~Hz}\right), 129.1(\mathrm{CH}), 127.9$ $(2 \times \mathrm{CH}), 127.5\left(\mathrm{CH},{ }^{3} J_{C-F}=7.8 \mathrm{~Hz}\right), 125.9\left(\mathrm{C},{ }^{2} \mathrm{~J}=\right.$ $15.8 \mathrm{~Hz}), 123.6\left(\mathrm{CH},{ }^{4} J_{C-F}=3.3 \mathrm{~Hz}\right), 117.8(\mathrm{CH})$, $114.8\left(\mathrm{CH},{ }^{2} J_{\mathrm{C}-F}=21.9 \mathrm{~Hz}\right), 26.2(\mathrm{CH}), 24.3(\mathrm{C}), 19.3$ $\left(2 \times \mathrm{CH}_{3}\right),-1.7\left(\mathrm{CH}_{3}\right),-1.8\left(\mathrm{CH}_{3}\right)$.

$\{[(1 Z)$-2,2-Dimethyl-3-(propan-2-yl)cyclopropylidene]methyl\}dimethylphenylsilane (10i).

Purified by flash column chromatography (petroleum ether).

Yield: $18 \mathrm{mg}$ (90\%); colorless oil.

IR (neat): 1720, 1463, 1427, 1368, 1289, 1246, 1176, 1113, 970, 840, 822, 794, 767, 728, $698 \mathrm{~cm}^{-1}$.

${ }^{1} \mathrm{H}$ NMR $\left(400 \mathrm{MHz}, \mathrm{CDCl}_{3}\right): \delta=7.57-7.53(\mathrm{~m}, 2 \mathrm{H})$, $7.37-7.34(\mathrm{~m}, 3 \mathrm{H}), 5.99(\mathrm{~d}, J=1.7 \mathrm{~Hz}, 1 \mathrm{H}), 1.36-$ $1.30(\mathrm{~m}, 1 \mathrm{H}), 1.11(\mathrm{~s}, 3 \mathrm{H}), 1.06(\mathrm{~s}, 3 \mathrm{H}), 1.02(\mathrm{~d}, J=$ $6.6 \mathrm{~Hz}, 3 \mathrm{H}), 0.99(\mathrm{~d}, J=6.6 \mathrm{~Hz}, 3 \mathrm{H}), 0.81(\mathrm{dd}, J=$ $10.2,1.7 \mathrm{~Hz}, 1 \mathrm{H}), 0.36(\mathrm{~s}, 6 \mathrm{H})$.

${ }^{13} \mathrm{C}$ NMR (100 MHz, $\left.\mathrm{CDCl}_{3}\right): \delta=160.9(\mathrm{C}), 139.9$ (C), $134.0(2 \times \mathrm{CH}), 128.9(\mathrm{CH}), 127.8(2 \times \mathrm{CH})$, $112.5(\mathrm{CH}), 35.6(\mathrm{CH}), 29.3(\mathrm{CH}), 26.9\left(\mathrm{CH}_{3}\right), 23.4$ $\left(\mathrm{CH}_{3}\right), 23.1 \quad\left(\mathrm{CH}_{3}\right), 20.4(\mathrm{C}), \quad 19.3 \quad\left(\mathrm{CH}_{3}\right),-1.7$ $\left(2 \times \mathrm{CH}_{3}\right)$. 
$\left\{\left[\left(3 R^{*} / S^{*}\right) \quad(1 Z)-2,2-d i m e t h y l-3-\left(\left(1 R^{*}\right)-1-p h e n y l-\right.\right.\right.$ ethyl)cyclopropylidene]methyl $\}$ dimethylphenylsilane $\left.(\mathbf{1 0 j} / \mathbf{1 0 j})^{\prime}\right)$.

The gold-catalyzed rearrangement of a 90:10 diastereoisomeric mixture of $\mathbf{9 j} / \mathbf{9 j}$ ' afforded a $65: 35$ mixture of $\mathbf{1 0 j} / \mathbf{1 0 j}$ ' [Yield: $34 \mathrm{mg}(81 \%)$ ]. Alternatively, the gold-catalyzed rearrangement of a 23:77 diasteromeric mixture of $\mathbf{9 j} / \mathbf{9 j}$ ' produced a 43:57 diastereoisomeric mixture of $\mathbf{1 0 j} / \mathbf{1 0 j}$ ' [Yield: 13 $\mathrm{mg}(77 \%)]$.

IR (neat): 1723, 1602, 1494, 1450, 1427, 1246, 1112, $968,841,827,786,729,697 \mathrm{~cm}^{-1}$.

Diastereomer $(\mathbf{1 0 j})$ :

${ }^{1} \mathrm{H}$ NMR $\left(400 \mathrm{MHz}, \mathrm{CDCl}_{3}\right): \delta=\delta 7.59-7.57(\mathrm{~m}$, $2 \mathrm{H}), 7.38-7.17(\mathrm{~m}, 8 \mathrm{H}), 6.13(\mathrm{~d}, J=1.3 \mathrm{~Hz}, 1 \mathrm{H})$, $2.55-2.43(\mathrm{~m}, 1 \mathrm{H}), 1.41-1.37(\mathrm{~m}, 1 \mathrm{H}), 1.37(\mathrm{~d}, J=$ $6.9 \mathrm{~Hz}, 3 \mathrm{H}), 1.11$ (s, 3H), 0.94 (s, 3H), 0.39 (s, 6H).

${ }^{13} \mathrm{C}$ NMR $\left(100 \mathrm{MHz}, \mathrm{CDCl}_{3}\right): \delta=159.9(\mathrm{C}), 147.8$ (C), 139.7 (C), $134.0(2 \times \mathrm{CH}), 129.0(\mathrm{CH}), 128.4$ $(2 \times \mathrm{CH}), 127.9(2 \times \mathrm{CH}), 126.8(2 \times \mathrm{CH}), 125.9$ $(\mathrm{CH}), 113.3(\mathrm{CH}), 39.9(\mathrm{CH}), 33.5(\mathrm{CH}), 26.5\left(\mathrm{CH}_{3}\right)$, $23.7\left(\mathrm{CH}_{3}\right), 21.0(\mathrm{C}), 19.6\left(\mathrm{CH}_{3}\right),-1.7\left(2 \times \mathrm{CH}_{3}\right)$.

Diastereomer (10j'):

${ }^{1} \mathrm{H}$ NMR $\left(400 \mathrm{MHz}, \mathrm{CDCl}_{3}\right): \delta=7.53-7.48(\mathrm{~m}, 2 \mathrm{H})$, 7.38-7.17 (m, 8H), $5.70($ br s, $1 \mathrm{H}), 2.54-2.43(\mathrm{~m}$, $1 \mathrm{H}), 1.36(\mathrm{~d}, J=6.9 \mathrm{~Hz}, 3 \mathrm{H}), 1.28(\mathrm{~m}, 1 \mathrm{H}), 1.17(\mathrm{~s}$, $6 \mathrm{H}), 0.334$ (s, 3H), 0.329 (s, 3H).

${ }^{13} \mathrm{C}$ NMR $\left(100 \mathrm{MHz}, \mathrm{CDCl}_{3}\right): \delta=159.1(\mathrm{C}), 147.1$ (C), $139.8(\mathrm{C}), 134.0(2 \times \mathrm{CH}), 128.9(\mathrm{CH}), 128.4$ $(2 \times \mathrm{CH}), 127.8(2 \times \mathrm{CH}), 127.3(2 \times \mathrm{CH}), 125.9$ $(\mathrm{CH}), 113.4(\mathrm{CH}), 39.8(\mathrm{CH}), 34.3(\mathrm{CH}), 26.9\left(\mathrm{CH}_{3}\right)$, $22.5\left(\mathrm{CH}_{3}\right), 20.4(\mathrm{C}), 19.3\left(\mathrm{CH}_{3}\right),-1.7\left(2 \times \mathrm{CH}_{3}\right)$.

HRMS (ESI): $m / z$ calcd for $\mathrm{C}_{22} \mathrm{H}_{28} \mathrm{SiNa}\left[\mathrm{M}+\mathrm{Na}^{+}\right]$: 343.18525; found: 343.18529 .

\section{Preparation and Gold-Catalyzed Rearrangement of $(R)-9$ a}

2-Benzyloxy-1-[2-(dimethylphenylsilyl)-3,3dimethylcycloprop-1-enyl]ethanone. (11).

To a solution of $( \pm)-10 \mathrm{a}(56.9 \mathrm{mg}, 0.161 \mathrm{mmol})$ in $\mathrm{CH}_{2} \mathrm{Cl}_{2}(2 \mathrm{~mL})$ at $0{ }^{\circ} \mathrm{C}$, was added Dess-Martin periodinane $(82.2 \mathrm{mg}, 0.194 \mathrm{mmol}, 1.2$ equiv). After $10 \mathrm{~min}$ at $0{ }^{\circ} \mathrm{C}$, the reaction mixture was warmed to $\mathrm{rt}$, stirred for further $10 \mathrm{~min}$ and then hydrolyzed with a saturated aqueous solution of $\mathrm{NaHCO}_{3}$. The resulting mixture was extracted with $\mathrm{Et}_{2} \mathrm{O}$ and the combined organic phases were washed with brine, dried over $\mathrm{Na}_{2} \mathrm{SO}_{4}$, filtered and concentrated under reduced pressure. The crude material was purified by flash column chromatography (petroleum ether/ $/ \mathrm{Et}_{2} \mathrm{O}$, $80: 20)$ to afford $52.7 \mathrm{mg}$ (93\%) of $\mathbf{1 1}$ as a yellow oil.

IR (neat): 1736, 1687, 1250, 1113, 1078, 835, 817, $780,733,697,655 \mathrm{~cm}^{-1}$.
${ }^{1} \mathrm{H}$ NMR $\left(400 \mathrm{MHz}, \mathrm{CDCl}_{3}\right): \delta=7.54-7.52(\mathrm{~m}, 2 \mathrm{H})$, 7.41-7.30 (m, 8H), 4.55 (s, 2H), $4.18(\mathrm{~s}, 2 \mathrm{H}), 1.25(\mathrm{~s}$, $6 \mathrm{H}), 0.49$ (s, 6H).

${ }^{13} \mathrm{C}$ NMR $\left(100 \mathrm{MHz}, \mathrm{CDCl}_{3}\right): \delta=192.1(\mathrm{C}), 148.0$ (C), 143.4 (C), 137.4 (C), $135.8(\mathrm{C}), 133.8(2 \times \mathrm{CH})$, $130.0(\mathrm{CH}), 128.6(2 \times \mathrm{CH}), 128.3(2 \times \mathrm{CH}), 128.2$ $(2 \times \mathrm{CH}), 128.1(\mathrm{CH}), 74.2\left(\mathrm{CH}_{2}\right), 73.3\left(\mathrm{CH}_{2}\right), 27.2$ $\left(2 \times \mathrm{CH}_{3}\right), 24.8(\mathrm{C}),-2.4\left(2 \times \mathrm{CH}_{3}\right)$.

HRMS (ESI): $m / z$ calcd for $\mathrm{C}_{22} \mathrm{H}_{26} \mathrm{OSiNa}\left[\mathrm{M}+\mathrm{Na}^{+}\right]$: 373.15943; found: 373.15948 .

\section{(R)-2-(Benzyloxy)-1-[2-(dimethylphenylsilyl)- 3,3-dimethylcycloprop-1-en-1-yl]ethan-1-ol [(R)-(8a)].}

To a solution of ketone $\mathbf{1 1}(51.4 \mathrm{mg}, 0.147 \mathrm{mmol})$ in $i \mathrm{PrOH}(3 \mathrm{~mL})$ at $\mathrm{rt}$, was added catalyst $(R, R)-[\mathrm{Ru}]-\mathbf{I}^{26}$ $\left(50 \mu \mathrm{L}, 0.17 \mathrm{M}\right.$ stock solution in $\mathrm{CH}_{2} \mathrm{Cl}_{2}, 0.0085$ mmol, $6 \mathrm{~mol} \%)$. After $15 \mathrm{~h}$ at $\mathrm{rt}$, more catalyst $(R, R)$-[Ru]-I (6 mol \%) was added. After $4 \mathrm{~h}$ at $\mathrm{rt}$, the reaction was still incomplete and another portion of catalyst $(R, R)$-[Ru]-I $(6 \mathrm{~mol} \%)$ was added. The reaction mixture was heated at $40{ }^{\circ} \mathrm{C}$ for $2 \mathrm{~h}$, then cooled to rt and concentrated under reduced pressure. The residue was purified by flash column chromatography (petroleum ether/ $\mathrm{Et}_{2} \mathrm{O}, 80: 20$ ) to afford $38.4 \mathrm{mg}$ (74\%) of optically active alcohol $(R)-8 \mathbf{a}$ as a colorless oil.

$[\alpha]_{20_{\mathrm{D}}}=-7.2\left(c 0.25, \mathrm{CHCl}_{3}\right)$.

The enantiomeric excess of $(R)-8 \mathbf{a}(\mathrm{ee}=75 \%)$ was determined by SFC [Daicel Chiralpak OD-H, 100 bar, sc $\mathrm{CO}_{2} / \mathrm{MeOH}$ (97:3), flow rate $5.0 \mathrm{~mL} / \mathrm{min}$, $\lambda=210 \mathrm{~nm}]$ after calibration with racemic sample: $\mathrm{t}_{\mathrm{R}}=5.38 \mathrm{~min}$ (minor) and $5.74 \mathrm{~min}$ (major), see Supporting Information.

(R)-\{2-[2-(Benzyloxy)-1-(methoxymethoxy)ethyl]3,3-dimethylcycloprop-1-en-1-yl \} dimethylphenylsilane $[(\boldsymbol{R})-(\mathbf{9 a})]$.

Alcohol $(R)-8 \mathbf{a}$ (ee $=75 \%$ ) was converted into the MOM ether $(R)-\mathbf{9 a}$, as described for the preparation of the racemic compound.

$[\alpha]_{20} \mathrm{D}=+16.0\left(c 0.5, \mathrm{CHCl}_{3}\right)$.

\section{Gold-Catalyzed Rearrangement of $(R)-9 a$}

The rearrangement of optically active $(R)-9 \mathbf{a}$ $(\mathrm{ee}=75 \%)$ catalyzed by $\mathrm{AuCl}(5 \mathrm{~mol} \%)\left(\mathrm{CH}_{2} \mathrm{Cl}_{2}, \mathrm{rt}\right.$, $8 \mathrm{~h}$ ) provided (silylmethylene)cyclopropane 10a [Yield: $23 \mathrm{mg}(95 \%)$ ] as a racemate (ee $=0 \%)$.

The enantiomeric excess of this latter product was determined by SFC [Daicel Chiralpak OJ-H, 100 bar, $\mathrm{sc} \mathrm{CO}_{2} / \mathrm{MeOH}$ (95:5), $\left.5.0 \mathrm{~mL} / \mathrm{min}, \lambda=220 \mathrm{~nm}\right]$ after calibration with an authentic sample of ( \pm -10a arising from the gold-catalyzed rearrangement of $( \pm)-9 \mathbf{a}$ : $\mathrm{t}_{\mathrm{R}}=2.99 \mathrm{~min}$ and $3.85 \mathrm{~min}$, see Supporting Information. 
$\left(\left(1 R^{*}, 3 S^{*}\right)-3-\{3-[(\right.$ tert-Butyldimethylsilyl)oxy]propyl\}-2,2-dimethylcyclopropylmethyl)dimethylphenylsilane (12).

To a solution of 10a (30 mg, $0.077 \mathrm{mmol})$ in EtOAc $(1.5 \mathrm{~mL})$ was added $5 \% \mathrm{Pd} / \mathrm{C}(4 \mathrm{mg}, 0.004 \mathrm{mmol}$, $5 \mathrm{~mol} \%)$. After $1 \mathrm{~h}$ stirring under an atmospheric pressure of $\mathrm{H}_{2}$, the reaction mixture was filtered through Celite (EtOAc) and the filtrate was evaporated under reduced pressure. The residue was purified by flash column chromatography (petroleum ether/EtOAc: 90/10) to provide $27 \mathrm{mg}(88 \%)$ of $\mathbf{1 2}$ as a colorless oil ( $\mathrm{dr}>95: 5)$. The relative configuration of 12 was assigned on the basis of the coupling constant value between the two cyclopropyl protons $(J=8.6 \mathrm{~Hz})$.

IR (neat): 1471, 1462, 1249, 1111, 1098, 833, 773, $726,698,661 \mathrm{~cm}^{-1}$.

${ }^{1} \mathrm{H}$ NMR $\left(400 \mathrm{MHz}, \mathrm{CDCl}_{3}\right): \delta=7.55-5.51(\mathrm{~m}, 2 \mathrm{H})$, $7.37-7.35(\mathrm{~m}, 3 \mathrm{H}), 3.60(\mathrm{t}, J=6.7 \mathrm{~Hz}, 2 \mathrm{H}), 1.59-1.50$ $(\mathrm{m}, 2 \mathrm{H}), 1.26-1.15(\mathrm{~m}, 2 \mathrm{H}), 0.98(\mathrm{~s}, 3 \mathrm{H}), 0.90(\mathrm{~s}, 9 \mathrm{H})$, $0.80(\mathrm{~s}, 3 \mathrm{H}), 0.72(\mathrm{dd}, J=14.8,5.0 \mathrm{~Hz}, 1 \mathrm{H}), 0.57$ (dd, $J=14.8,8.6 \mathrm{~Hz}, 1 \mathrm{H}$ ), 0.47 (apparent td, $J=8.6,5.0$ $\mathrm{Hz}, 1 \mathrm{H}$ ), 0.36 (ddd, $J=8.6,7.7,6.5 \mathrm{~Hz}, 1 \mathrm{H}), 0.302$ (s, $3 \mathrm{H}), 0.298$ (s, 3H), 0.06 (s, 6H).

${ }^{13} \mathrm{C}$ NMR $\left(100 \mathrm{MHz}, \mathrm{CDCl}_{3}\right): \delta=139.8(\mathrm{C}), 133.8$ $(2 \times \mathrm{CH}), 128.9(\mathrm{CH}), 127.8(2 \times \mathrm{CH}), 63.5\left(\mathrm{CH}_{2}\right)$, $33.4\left(\mathrm{CH}_{2}\right), 29.4\left(\mathrm{CH}_{3}\right), 26.8(\mathrm{CH}), 26.1\left(3 \times \mathrm{CH}_{3}\right)$, $21.9(\mathrm{CH}), 20.8\left(\mathrm{CH}_{2}\right), 18.5(\mathrm{C}), 17.2(\mathrm{C}), 15.0\left(\mathrm{CH}_{3}\right)$, $9.9\left(\mathrm{CH}_{2}\right),-2.8\left(\mathrm{CH}_{3}\right),-2.9\left(\mathrm{CH}_{3}\right),-5.1\left(2 \times \mathrm{CH}_{3}\right)$.

HRMS (ESI): $\mathrm{m} / \mathrm{z}$ calcd for $\mathrm{C}_{23} \mathrm{H}_{43} \mathrm{OSi}_{2}\left[\mathrm{M}+\mathrm{H}^{+}\right]$: 391.28470; found: 391.28444 .

Supporting Information for this article is available online at http://www.thiemeconnect.com/products/ejournals/journal/10.1055/s00000084.

\section{Acknowledgment}

One of us (A.A.) thanks the MNSER for a PhD grant.

\section{References}

(1) For reviews, see: (a) Binger, P.; Büch, H. M. Top. Curr. Chem. 1987, 135, 77. (b) Fox, J. M.; Yan, N. Curr. Org. Chem. 2005, 9, 719. (c) Nakamura, M.; Isobe, H.; Nakamura, E. Chem. Rev. 2003, 103, 1295. (d) Rubin, M.; Rubina, M.; Gevorgyan, V. Synthesis 2006, 1221. (e) Rubin, M.; Rubina, M.; Gevorgyan, V. Chem. Rev. 2007, 107, 3117. (f) Marek, I.; Simaan, S.; Masarwa, A. Angew. Chem. Int. Ed. 2007, 46, 7364. (g) Miege, F.; Meyer, C.; Cossy, J. Beilstein J. Org. Chem. 2011, 7, 717. (h) Zhu, Z.-B.; Wei, Y.; Shi, M. Chem. Soc. Rev. 2011, 40, 5534. (i) Archambeau, A.; Miege, F; Cossy, J.; Meyer, C. In The Chemistry of Organogold Complexes, Rappoport, Z.; Liebman, J. F.; Marek, I., Ed.; Wiley: Chichester, 2014, 631. (j) Rubin, M.; Ryabchuk, P. G. Chem. Heterocycl. Compd. 2012, 48, 126. (k) Müller, D. S.; Marek, I. Chem. Soc. Rev. 2016, DOI: $10.1039 / \mathrm{c} 5 \mathrm{cs} 00897 \mathrm{~b}$.
(2) For selected recent contributions, see: (a) Zhang, F.-G.; Eppe, G.; Marek, I. Angew. Chem. Int. Ed. 2016, 55, 714. (b) Archambeau, A.; Nguyen, D.-V.; Meyer, C.; Cossy, J. Chem. Eur. J. 2016, 22, 6100. (c) Nakano, T.; Endo, K.; Ukaji, Y. Chem. Asian. J. 2016, 11, 713. (d) Le, P. Q.; May, J. A. J. Am. Chem. Soc. 2015, 137, 12219. (e) Archambeau, A.; Miege, F.; Meyer, C.; Cossy, J. Acc. Chem. Res. 2015, 48, 1021. (f) Müller, D. S.; Marek, I. J. Am. Chem. Soc. 2015, 137, 15414. (g) González, M. J.; González, J.; López, L. A.; Vicente, R. Angew. Chem. Int. Ed. 2015, 54, 12139. (h) Xu, X.; Deng, Y.; Yim, D. N.; Zavalij, P. Y.; Doyle, M. P. Chem. Sci. 2015, 6, 2196. (i) Zhang, H.; Wang, B.; Yi, H.; Zhang, Y.; Wang, J. Org. Lett. 2015, 17, 3322. (j) Sawano, T.; Hashizume, M.; Nishimoto, S.; Ou, K.; Nishimura, T. Org. Lett. 2015, 17, 2630. (k) Parra, A.; Amenós, L.; Guisán-Ceinos, M.; López, A.; García Ruano, J. L.; Tortosa, M. J. Am. Chem. Soc. 2014, 136, 15833. (l) Tian, B.; Liu, Q.; Tong, X.; Tian, P.; Lin, G.Q. Org. Chem. Front. 2014, 1, 1116. (m) Zhang, H.; Li, C.; Xie, G.; Wang, B.; Zhang, Y.; Wang, J. J. Org. Chem. 2014, 79, 6286.

(3) Zhu, Z.-B.; Shi, M. Chem. Eur. J. 2008, 14, 10219.

(4) Bauer, J. T.; Hadfield, M. S.; Lee, A.-L. Chem. Commun. 2008, 6405.

(5) (a) Li, C.; Zeng, Y.; Wang, J. Tetrahedron Lett. 2009, 50, 2956. (b) Hadfield, M. S.; Bauer, J. T.; Glen, P. E.; Lee, A.-L. Org. Biomol. Chem. 2010, 8, 4090. (c) Seraya, E.; Slack, E.; Ariafard, A.; Yates, B. F.; Hyland, C. J. T. Org. Lett. 2010, 12, 4768. (d) Hadfield, M. S.; Lee, A.L. Chem. Commun. 2011, 47, 1333. (e) Mudd, R. J.; Young, P. C.; Jordan-Hore, J. A.; Rosair, G. M.; Lee, A.L. J. Org. Chem. 2012, 77, 7633. (f) Young, P. C.; Hadfield, M. S.; Arrowsmith, L; Macleod, K. M.; Mudd, R. J.; Jordan-Hore, J. A.; Lee, A.-L. Org. Lett. 2012, 14, 898.

(6) (a) Zhou, Y.; Trewyn, B. G.; Angelici, R. J.; Woo, L. K. J. Am. Chem. Soc. 2009, 131, 11734. (b) Benitez, D.; Shapiro, N. D.; Tkatchouk, E.; Wang, Y.; Goddard III, W. A.; Toste, F. D. Nature Chem. 2009, 1, 482. (c) Miege, F.; Meyer, C.; Cossy, J. Org. Lett. 2010, 12, 4144. (d) Miege, F.; Meyer, C.; Cossy, J. Chem. Eur. J. 2012, 18, 7810 .

(7) (a) Baird, M. S.; Hussain, H. H.; Nethercott, W. J. Chem. Soc., Perkin Trans 1 1986, 1845. (b) Simaan, S.; Masarwa, A.; Zohar, E.; Stanger, A.; Bertus, P.; Marek, I. Chem. Eur. J. 2009, 15, 8449.

(8) Rajabi, N. A.; Atashgah, M. J.; BabaAhmadi, R.; Hyland, C.; Ariafard, A. J. Org. Chem. 2013, 78, 9553.

(9) For monosubstituted cyclopropenes possessing a substituent able to stabilize an adjacent positive charge, theoretical studies show that binding of a cationic gold phosphine complex occurs in an unsymmetrical fashion through the unsubstituted carbon and subsequent kinetically controlled ring-opening leads to the less substituted gold carbenoid, see: Hadfield, M. S.; Häller, L. J. L.; Lee, A.-L.; Macgregor, S. A.; O’Neill, J. A. T.; Watson, A. M. Org. Biomol. Chem. 2012, 10, 4433.

(10) Wierschke, S. G.; Chadrasekhar, J.; Jorgensen, W. L. J. Am. Chem. Soc. 1985, 107, 1496.

(11) (a) Li, J.; Sun, C.; Demerzhan, S.; Lee, D. J. Am. Chem. Soc. 2011, 133, 12964. For a DFT study of the mechanism which involves a [1,2]-silyl shift leading to a cyclopropyl platinum carbenoid intermediate, see: (b) Fang, R.; Yang, L.; Wang, Q. Organometallics 2012, 31,4020 .

(12) The configuration of the (silylmethylene)cyclopropanes resulting from the gold-catalyzed rearrangement of (silylcyclopropenyl)methyl ethers was assigned by 
analogy with the results observed in the case of substrates $9 \mathbf{a}, 9 \mathbf{b}$ and $9 \mathbf{c}$. The $(Z)$ configuration of the resulting products $10 \mathbf{a}, 10 \mathbf{b}$ and $10 \mathbf{c}$ was assigned by NMR (NOESY), see Supporting Information.

(13) For a review on gold-catalyzed $\mathrm{C}\left(\mathrm{sp}^{3}\right)-\mathrm{H}$ bond functionalization including processes mediated by a 1,5-hydride shift, see: Xie, J.; Pan, C.; Abdukader, A.; Zhu, C. Chem. Soc. Rev. 2014, 43, 5245.

(14) After elimination of acrolein and benzaldehyde in 5a and $\mathbf{5 b}$, respectively, the resulting intermediate species formally possesses a zwiterrionic character (allyl cation and allyl metal).

(15) Bolte, B.; Odabachian, Y.; Gagosz, F. J. Am. Chem. Soc. 2010, 132, 7294.

(16) Jones, G. R.; Landais, Y. Tetrahedron 1996, 52, 7599.

(17) Basheer, A.; Masaaki, M.; Marek I. Org. Lett. 2011, 13, 4076.

(18) Mengel, A.; Reiser, O. Chem. Rev. 1999, 99, 1191.

(19) Lemière, G.; Gandon, V.; Agenet, N.; Goddard, J.-P.; de Kozak, A.; Aubert, C.; Fensterbank, L.; Malacria, M. Angew. Chem. Int. Ed. 2006, 45, 7596.

(20) Mézailles, N.; Ricard, L.; Gagosz, F. Org. Lett. 2005, 7, 4133.

(21) Nieto-Oberhuber, C.; López, S.; Muñoz, M. P.; Cárdenas, D. J.; Buñuel, E.; Nevado, C.; Echavarren, A. M. Angew. Chem. Int. Ed. 2015, 44, 6146.

(22) Control experiments revealed that silylmethylenecyclopropane 10a reacted further in the presence of the phosphine gold catalysts and evolved to numerous (unidentified) products. Monitoring the reaction temperature did not improve the results.

(23) Hashmi, A. S. K.; Weyrauch, J. P.; Rudolph, M.; Kuperjovic, E. Angew. Chem. Int. Ed. 2004, 43, 6545.

(24) Alkynes were preferentially activated in the goldcatalyzed cycloisomerization of 1,5-cyclopropene-ynes, having a terminal, an aryl- or an alkyl-substituted triple bond tethered to the $\mathrm{C} 3$ atom of the cyclopropene, see: (a) Li, C.; Zeng, Y.; Zhang, H.; Feng, J.; Zhang, Y.; Wang, J. Angew. Chem. Int. Ed. 2010, 49, 6413. (b) Zhou, Q.; Li, Y. J. Am. Chem. Soc. 2014, 136, 1505. By contrast, an alkynylsilane was compatible with the $\mathrm{Pt}$-catalyzed isomerization of silylcyclopropenes into silylallenes, see ref. (11).

(25) (a) Allen, F. H. Tetrahedron 1982, 38, 645. (b) Fattahi, A.; McCarthy, R. E.; Ahmad, M. R.; Kass, S. R. J. Am. Chem. Soc. 2003, 125, 11746.

(26) Matsumura, K.; Hashiguchi, S.; Ikariya, T.; Noyori, R. J. Am. Chem. Soc. 1997, 119, 8738.

(27) Yamakawa, M.; Yamada, I.; Noyori, R. Angew. Chem. Int. Ed. 2001, 40, 2818.

(28) For a review allylic $A^{1,3}$ strain, see: R. W. Chem. Rev. 1989, 89, 1841. 
Gold-Catalyzed Rearrangement of (Silylcyclopropenyl)methyl ethers

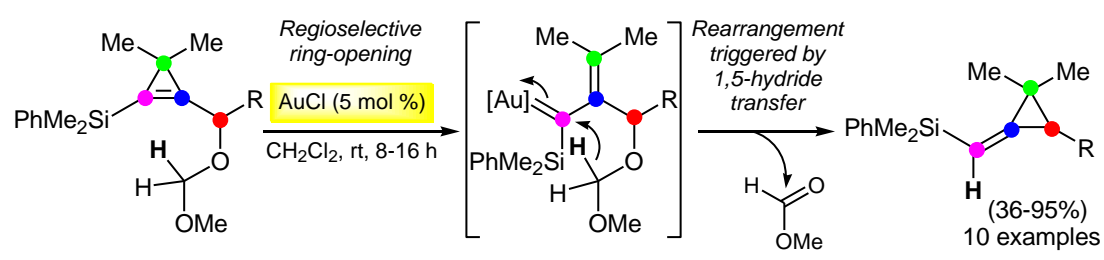

$\mathrm{R}=\mathrm{CH}_{2} \mathrm{OBn},\left(\mathrm{CH}_{2}\right)_{3} \mathrm{OTBS},\left(\mathrm{CH}_{2}\right)_{2} \mathrm{Ph},\left(\mathrm{CH}_{2}\right)_{3} \mathrm{CH}=\mathrm{CH}_{2},\left(\mathrm{CH}_{2}\right)_{2}=\mathrm{TMS}, \mathrm{Ph}, 2-\mathrm{FC}_{6} \mathrm{H}_{4}, \mathrm{Pr}, \mathrm{CH}(\mathrm{Me}) \mathrm{Ph}$ 